\title{
Diverse roles of neurotensin agonists in the central nervous system
}

\section{Mona Boules*, Zhimin Li, Kristin Smith, Paul Fredrickson and Elliott Richelson}

Neuropsychopharmacology Laboratory, Department of Neuroscience, Mayo Clinic Florida, Jacksonville, FL, USA

\section{Edited by:}

Hubert Vaudry, University of Rouen,

France

\section{Reviewed by:}

Sarah J. Spencer, RMIT University, Australia

Jean H. Costentin, University of

Rouen, France

*Correspondence:

Mona Boules, Neuropsychopharmacology Laboratory,

Department of Neuroscience, Mayo

Clinic, 4500 San Pablo Road,

Jacksonville, FL 32224, USA.

e-mail:boules.mona@mayo.edu
Neurotensin (NT) is a tridecapeptide that is found in the central nervous system (CNS) and the gastrointestinal tract. NT behaves as a neurotransmitter in the brain and as a hormone in the gut. Additionally, NT acts as a neuromodulator to several neurotransmitter systems including dopaminergic, sertonergic, GABAergic, glutamatergic, and cholinergic systems. Due to its association with such a wide variety of neurotransmitters, NT has been implicated in the pathophysiology of several CNS disorders such as schizophrenia, drug abuse, Parkinson's disease (PD), pain, central control of blood pressure, eating disorders, as well as, cancer and inflammation. The present review will focus on the role that NT and its analogs play in schizophrenia, endocrine function, pain, psychostimulant abuse, and PD.

Keywords: neurotensin, endocrinology, schizophrenia, pain, psychostimulant abuse, central nervous system

\section{INTRODUCTION}

Neurotensin (NT) is a 13 amino acid neuropeptide ( $p$ Glu-LeuTyr-Glu-Asn-Lys-Pro-Arg-Arg-Pro-Tyr-Ile-Leu) that was first isolated from bovine hypothalamus by Carraway and Leeman (1973). It is abundant in gastrointestinal tract where it plays a role in gut motility. NT has also been detected in peripheral organs including: heart, liver, lung, pancreas, spleen, and small intestine. It is a paracrine and endocrine modulator of the cardiovascular system and of the digestive tract and acts as a growth factor on a variety of normal and cancerous cells. In addition, NT is widely distributed in the central nervous system (CNS), with the highest concentration in the amygdala, lateral septum, ventral tegmental area (VTA), and substantia nigra (SN).

In brain, NT plays a role in naloxone-independent antinociception (Clineschmidt et al., 1979), hypothermia (Bissette et al., 1976), control of anterior pituitary hormone secretion, and muscle relaxation (Kitabgi et al., 1992). NT also controls central blood pressure, and inflammation (St-Gelais et al., 2006 for review). The physiological functions of NT have been recently reviewed (Mustain et al., 2011).

Many literature reviews have presented the basic role of brain NT through its relationship with dopaminergic mesotelencephalic projection system and its modulating glutamatergic transmission and other signals (Seutin, 2005; Boules et al., 2006; Antonelli et al., 2007; Ferraro et al., 2008). The current review discusses the potential clinical function of NT and the potential clinical use of its analogs as novel therapy for neuropsychiatric disorders such as schizophrenia, addiction, Parkinson's disease (PD), and pain.

\section{NEUROTENSIN RECEPTORS}

Neurotensin mediates its effects through three NT receptors (NTRs), the high affinity NTS1, the low affinity NTS2, and NTS3. Both NTS1 and NTS2 are G-protein coupled receptors, with seven-transmembrane domain. NTS1, the most studied NTR, is expressed in both neurons and glial cells and is broadly distributed in the CNS including medial septal nucleus, nucleus basalis magnocellularis, suprachiasmatic nucleus, $\mathrm{SN}$, and VTA (Elde et al., 1990) as well as small dorsal root ganglion neurons of the spinal cord (Zhang et al., 1995). Activation of NTS1 induces excitatory effect through G-proteins, resulting in intracellular calcium influx. In turn, there is increased intracellular levels of cAMP, cGMP, and IP3; and increased activities of PLC, PKC, and Na+/K+-ATPase (Gilbert and Richelson, 1984; Watson et al., 1992; Yamada and Richelson, 1993; Hermans et al., 1994; Slusher et al., 1994; Poinot-Chazel et al., 1996; Lopez Ordieres and Rodriguez de Lores Arnaiz, 2000; Trudeau, 2000). NTS1 has a close association with dopaminergic and glutamatergic systems.

A high density of NTS1 receptors is co-localized with dopamine (DA) neurons in the ventral mesencephalon (Brouard et al., 1992; Nicot et al., 1995; Boudin et al., 1998). NT antagonizes DA effects at D2 receptors via NTS1/D2 receptor-receptor interaction (Jiang et al., 1994; Farkas et al., 1996). Several studies suggested that NTS1 receptors on mesencephalic DA neurons play an important role in sensitization to psychostimulant drugs and drug addiction (Binder et al., 2001a; Berod and Rostene, 2002; Panayi et al., 2005). Our recent work shows that (1) NTS1 knockout mice $\left(\mathrm{NTS}^{-I-}\right)$ mice are spontaneously hyperactive and more sensitive to D-amphetamine-induced hyperactivity (Liang et al., 2010); (2) $\mathrm{NTS1}^{-/-}$mice have higher basal levels of DA and higher levels of amphetamine-induced DA release in striatum as compared with results for WT mice (Liang et al., 2010); and (3) $\mathrm{NTS1}^{-/-}$have abnormal D2/D1 ratio in striatum (Liang et al., 2010), leading to a decrease of $\mathrm{D}$-amphetamine-induced glutamate and GABA release in striatum (Li et al., 2010b). The results suggest that NTS1 through possible modulation of DA receptor plays an important role in the dysregulation of striatal DA function which is thought to be secondary to a glutamate deficiency in schizophrenia through possible modulation of DA receptor. Additionally, a possible interaction between NTS1 and D1 receptor in medial prefrontal cortex (mPFC) has been proposed in one of our recent studies (Li et al., 
2010c). The same work also shows that there are significantly lower basal glutamate levels and lower density of $N$-methyl-D-aspartate (NMDA) receptor 2A subunit in the $\mathrm{mPFC}$ of NTS1 null mice as compared with results for WT mice (Li et al., 2010c). These data are consistent with the hypothesis that NTS1 is involved with the pathophysiology of the hypofunction of the glutamatergic system in schizophrenia.

The relationship between NTS1 and glutamatergic system has been investigated by Antonelli's group for years. Activation of NTS1 promotes and reinforces endogenous glutamate signaling in discrete brain regions by increasing the activation of PKC and leading to phosphorylation of the NMDA receptor. NTS1 receptors are highly expressed in nigro-striatal dopaminergic neurons, which degenerate in PD. It has been hypothesized (Antonelli et al., 2007) that in Parkinson's patients, possible elevated NT levels in the basal ganglia cause the NTS1 enhancement of excitotoxic glutamate signaling contributing to the DA neuron neurodegeneration in SN. However, paradoxically, NT or an NTS1 agonist has antiparkinson-like effect (Jolicoeur et al., 1991; Boules et al., 2001b). The discrepancy is likely due to different routes and time course of administration: local infusion in the striatum or SN for 60 min versus acute systemic i.p. administration. We have discussed previously that the effects of a NTR agonist given outside the brain cannot be predicted from studies in which a NTR agonist is injected into discrete areas of the brain (Richelson et al., 2003). Both groups agree that there is a critical role for NTS1 in PD.

NTS2 is localized mainly in the olfactory system, the cerebral and cerebellar cortices, the hippocampal formation, and selective hypothalamic nuclei, VTA, and SN. Importantly, strong expression of NTS2 receptors is in the areas related to pain, namely, the periaqueductal gray (PAG) and the rostral ventrolateral medulla (RVLM). Local administration of NT into the PAG and RVLM induces opioid-independent analgesia (Behbehani, 1992) through non-NTS1 dependent mechanisms (Dubuc et al., 1994). Antisense oligonucleotide knockdown of NTS2 receptor significantly decreases NT-induced analgesia, while oligodeoxynucleotides against NTS1 had no effect in this regard. These results are also supported by recent data from NT (Remaury et al., 2002) and the NTS2 receptor-selective agonist NT79 (Boules et al., 2010). Taken together it suggests that NTS2 plays an important role in pain.

NTS3/sortilin is a single transmembrane amino acid receptor, structurally unrelated to either NTS1 or NTS2. Its mRNA is expressed throughout the brain with high levels of expression in the SN, hippocampal formation, supraoptic nucleus, piriform and cerebral cortices, and medial and lateral septal nuclei (Mazella, 2001; Sarret et al., 2003). NTS3/sortilin participates in the modulation of NT intracellular sorting (hence the name "sortilin") and signaling processes (Sarret et al., 2003) and has been associated with the phosphatidylinositol 3-kinase and mitogenactivated protein kinase pathways in glial cells (Martin et al., 2003). NTS3/sortilin has been implicated in cell death in responsive cells including neurons. This is thought to be due to the ability of NTS3/sortilin to bind the unprocessed form of nerve growth factor (proNGF) (Nykjaer et al., 2004). Additionally, SorLA/LR11, a mosaic protein of the vacuolar protein sorting 10 protein (Vps10p) domain receptor family and the low density lipoprotein receptor (LDLR) family, represents the fourth NTR (NTS4). It has a similar structure as NTS3/sortilin, with a wide distribution in the brain, especially in the hippocampus, cerebellum, cingulate gyrus, entorhinal cortex, red nucleus, and oculomotor nucleus (Motoi et al., 1999). NTS4 may be involved in the intracellular trafficking and in termination of NT signaling (Jacobsen et al., 2001).

\section{NT AND NEUROTRANSMITTER SYSTEMS}

Neurotensin acts as a primary neurotransmitter as well as a modulator of other neurotransmitter systems such as the dopaminergic, glutamatergic, GABAergic, cholinergic, and serotonergic systems (Rakovska et al., 1998; Ferraro et al., 2008; Petkova-Kirova et al., 2008). The functional and anatomical NT/DA interactions have been the most extensively studied and reviewed (Binder et al., 2001a; Jomphe et al., 2006; Fawaz et al., 2009; Thibault et al., 2011; Tanganelli et al., 2012).

\section{NEUROTENSIN AND DOPAMINE}

As mentioned in the previous section, NT and DA are co-localized in a subpopulation of mesencephalic neuron within the VTA (Hokfelt et al., 1984; Seroogy et al., 1988; Bean and Roth, 1992). Additionally, NT-like immunoreactivity is highly expressed in areas enriched with DA cell bodies and nerve terminals such as SN, VTA, neostriatum, and nucleus accumbens (NA) (Quirion et al., 1982). NT also forms synaptic contacts with a subpopulation of tyrosine hydroxylase (TH) immunoreactive neurons (Woulfe and Beaudet, 1989). These data strongly indicate a modulatory function of NT on DA neurotransmission.

Neurotensin directly or indirectly (e.g., through glutamate release) modulates DA neurotransmission. NT can modulate DA through: (1) up-regulating TH gene expression (Burgevin et al., $1992 \mathrm{a}, \mathrm{b})$ or (2) decreasing the DA binding affinity for the DA $\mathrm{D}_{2}$ receptors (Fuxe et al., 1992a; Li et al., 1995). NT also opposes DA D 2 receptor agonist-induced auto-inhibition of DA cell firing (Shi and Bunney, 1992). Allosteric receptor-receptor interactions between NT and DA $D_{2}$ receptors, as well as second messenger-dependent receptor alterations, such as phosphorylation and dephosphorylation, have also been implicated (see Fuxe et al., 1992b for review). It is important to mention that within the terminal fields, NT opposes the effects of DA both pre- and post-synaptically, leading either to an increase or to a decrease in DA transmission, depending on the intrinsic anatomical location of NTRs (for a more comprehensive review of the modulatory effects of NT on DA neurotransmission, we refer the reader to Binder et al. (2001a) and Kinkead and Nemeroff (2004).

\section{NT AND SEROTONIN}

Neurotensin receptors are present on serotonergic neurons in the nucleus raphe magnus and dorsal raphe, where NT causes an increase in their firing rates (Jolas and Aghajanian, 1996; Li et al., 2001). Therefore, NT has been proposed to play a role in functions known to be affected by the serotonergic system including antinociception (Buhler et al., 2005; Boules et al., 2010), sleep-wake cycle (Jolas and Aghajanian, 1997), and stress (Corley et al., 2002).

\section{NT AND GLUTAMATE}

There has been controversy regarding the effect of NT on glutamate release and modification of the glutamatergic and NMDA 
receptors. NT increases glutamate release in the striatum, globus pallidus, frontal cortex, and SN (Ferraro et al., 2011, 2012) implicating NT in conditions such as stroke, Alzheimer's disease, and PD.

Others have reported that systemic administration of NT analogs blocks ethanol-induced increases in glutamate levels in the striatum (Li et al., 2011), and decreases phencyclidine (PCP)induced increases in glutamate in the prefrontal cortex ( $\mathrm{Li}$ et al., 2010a). These data support the idea that the antipsychotic-like effects of NT may be mediated in part by its modulatory effect on glutamate.

\section{NT AND HYPOTHALAMIC-PITUITARY AXIS EFFECT OF NT ON HORMONE RELEASE}

The presence of NT in the anterior pituitary gland and hypothalamus and its storage and release at the median eminence implicate $\mathrm{NT}$ and its receptors in neuroendocrine regulation (Rostene and Alexander, 1997). NT is thought to possess a paracrine or an autocrine role within the hypothalamus and the anterior pituitary (Bachelet et al., 1997; Bello et al., 2004). NT stimulates both directly and indirectly, the synthesis of corticotrophin releasing hormone $(\mathrm{CRH})$, gonadotropin-releasing hormone (GnRH) (Cooke et al., 2009), growth hormone-releasing hormone (GHRH) (Blackburn et al., 1980), and prolactin secretion at anterior pituitary and median eminence (Memo et al., 1986).

\section{CRH-ACTH}

Neurotensin stimulates the activity of the hypothalamic-pituitary $\mathrm{CRH}$-adrenocorticotropin hormone (ACTH) system. Central administration of NT increases ACTH and corticosterone in the presence of $\mathrm{CRH}$ receptor activation in the paraventricular nucleus (PVN) (Nussdorfer et al., 1992; Rowe et al., 1995). The modulatory action of NT on the pituitary-adrenocortical function in rats has been reported to be biphasic. The lower dose of NT exerts a stimulatory effect while the higher dose appears to have an inhibitory effect on both the pituitary-ACTH release and adrenocortical secretion (Malendowicz and Nussdorfer, 1994). NT also enhances the release of both $\mathrm{CRH}$-ir and ACTH-ir in rat adrenal medulla (Mazzocchi et al., 1997).

\section{Gonadotropic hormones}

Many neurons in the anteroventral periventricular (AVPV) and medial preoptic nuclei (MPN) express estrogen receptors and project to GnRH neurons (Smith and Wise, 2001). Surprisingly, $\mathrm{GnRH}$ neurons do not seem to possess intracellular estrogen receptors (Herbison and Theodosis, 1993) and evidence suggests that other neurons mediate the stimulatory effects of estrogen on GnRH secretion (Shivers et al., 1983). Interestingly, GnRH neurons were found to express NTS1 receptors (Herbison and Theodosis, 1992) and GABA receptors (Herbison et al., 1993). The number of GnRH neurons expressing NTS1-mRNA peaks during proestrus suggesting that NT directly stimulates GnRH neurons contributing to luteinizing hormone (LH) surge (Smith and Wise, 2001). There has been some controversy regarding the role of NT on LH surge. While some report that the administration of NT directly into the medial preoptic area (where $\mathrm{GnRH}$ cell bodies reside) evokes pre-ovulatory GnRH/LH surge (Alexander et al., 1989a), others indicate that NT has no effect on GnRH-stimulated LH release (Leiva and Croxatto, 1994). The former group showed that immunoneutralization of $\mathrm{NT}$ in the preoptic region attenuates the LH surge induced by estrogen and progesterone treatment in ovariectomized rats (Alexander et al., 1989b). The effect of NT on LH secretion requires intact dopaminergic and alpha adrenergic systems (Akema and Kimura, 1989).

\section{Growth hormone}

Neurotensin is co-expressed with growth hormone $(\mathrm{GH})$ releasing factor in the arcuate nucleus (Niimi et al., 1991) and modulates GH release. NT regulates GH secretion, in prepubertal children and adults (Bozzola et al., 1998a), as well as in neonates (Bozzola et al., 1998b), through the modulation of somatostatin release from the median eminence. In rats, estrogen plays a facilitatory role on NTinduced GH release that is independent of hypothalamic GHRH or somatostatin release (Ibanez et al., 1993).

\section{Prolactin}

With respect to prolactin release, NT has opposite actions, an inhibitory effect at the hypothalamic site and an excitatory effect at the pituitary. NT elevates plasma prolactin and GH levels in both normal and estrogen-progesterone pretreated male rats (Rivier et al., 1977). The inhibitory action of NT on prolactin release is mediated by the release of DA into the hypophyseal portal vein, which delivers the neurotransmitter to the anterior pituitary gland causing inhibition of prolactin release (Vijayan et al., 1988; McCann and Vijayan, 1992; Pan et al., 1992).

\section{Thyroid hormones}

Neurotensin also participates in the neuroendocrine control of the thyroid hormones by regulating thyroid releasing hormone (TRH) function and thyroid stimulating hormone (TSH) secretion. These data indicate that NT is involved in the metabolic actions of these hormones. The role of NT in the hypothalamic-anterior pituitarythyroid axis and the functional cooperation between NT and thyroid hormones are excellently reviewed by Stolakis et al. (2010).

\section{Effect of NT on feeding}

In addition to its presence in the CNS NT is also found in neuroendocrine cells of the small bowel. There, NT participates in enteric digestive processes, gut motility, and intestinal inflammatory mechanisms. It also plays an important role in intestinal lipid metabolism, thus controlling appetite, weight status, and food intake (Kalafatakis and Triantafyllou, 2011). Additionally, NT exerts central control on blood glucose, feeding patterns, and body weight.

Centrally administered NT reduces appetite (Luttinger et al., 1982; Hawkins, 1986; Cooke et al., 2009), an effect that is mainly mediated by NTS1 (Remaury et al., 2002; Kim et al., 2008; Kim and Mizuno, 2010).

The anorectic effect of centrally administered NT is potentiated by peripheral injection of DA agonists, L-DOPA and bromocriptine, results suggesting that the effect of NT may be mediated by its ability to increase the activity of dopaminergic neurotransmission in the CNS (Hawkins et al., 1986).

Similar effects were shown for the NT agonist, PD149163, in rats and ob/ob mice (Feifel et al., 2010a) as well as the non-selective 
NT agonist NT69L in Sprague-Dawley and in obese Zucker rats (Boules et al., 2000). The later study also showed that the effect of NT69L on food intake and body weight is due to functional interactions of NT with brain amines, and metabolic and endocrinological systems. NT69L transiently increases blood glucose and corticosterone levels and decreases TSH and T4 in Sprague-Dawley and in Zucker rats. NT69L also decreases norepinephrine in both the hypothalamus and NA, and increases DA, its metabolite 3,4-dihydroxyphenylacetic acid (DOPAC), and serotonin. These results indicate that feeding and energy expenditures are modulated by the interplay of hormones and neurotransmitters in the CNS (Brunetti et al., 2005).

Additionally, the effect of NT on feeding and body weight is also mediated, in part, by its action on the anorexigenic hormone leptin, which is secreted by adipocytes and regulates food intake by acting on hypothalamic neurons including NT-producing neurons (Beck et al., 1998; Sahu et al., 2001). Leptin together with insulin and $\alpha$-melanocyte-stimulating hormones increase NT expression in the hypothalamus (Sahu, 1998; Cui et al., 2005). Similarly, the anorectic effect of leptin is at least partly mediated through central NTS1 and the leptin-NTS1 signaling pathway is involved in the regulation of food intake and the in the control of energy balance (Leinninger et al., 2011) since the lack of NTS1 reduces sensitivity to the anorectic action of leptin, causing hyperphagia and abnormal weight gain (Kim et al., 2008).

\section{EFFECT OF HORMONES ON NT SYNTHESIS AND RELEASE IN HYPOTHALAMIC-PITUITARY AXIS}

As NT modulates hypothalamic-pituitary axis (HPA) hormones, circulating hormones influence NT synthesis in the hypothalamus and anterior pituitary, results that suggest that NT mediates feedback effects of the hormones on neuroendocrine cells (Rostene and Alexander, 1997). Estrogen and progesterone regulate the activity of NT-synthesizing neurosecretory cells located in the hypothalamic arcuate nucleus (Alexander, 1999). Estrogen increases the secretion of NT at the median eminence and alters NT binding and NTS1-mRNA expression in the rostral preoptic nucleus (Moyse et al., 1988; Alexander, 1993; Watanobe and Takebe, 1993; Alexander and Leeman, 1994). GHRH neurosecretory cells synthesize NT under basal conditions (Niimi et al., 1991) and GH injection increases NT plasma levels in human (Schimpff et al., 1994).

Neurotensin's endocrine activity, and its modulatory effects on several neurotransmitter systems, kindled many studies suggesting that NT plays a role in the pathophysiology of several CNS disorders including PD, schizophrenia, and psychostimulant and nicotine addiction as well as pain and eating disorders (Caceda et al., 2006).

\section{NT AND NEUROPSYCHIATRIC DISORDERS SCHIZOPHRENIA}

Schizophrenia is a devastating psychotic disorder that affects approximately $1 \%$ of the population worldwide. The onset of illness usually occurs relatively early in life with most patients experiencing long-lasting adverse effects accompanied by severe impairment (reviewed in Carpenter and Buchanan (1994). The disease is manifested by positive symptoms (delusions, hallucinations, and an altered perception of reality), and negative symptoms (apathy, cognitive blunting, and social withdrawal), as well as a disorganization of thought and behavior. Many schizophrenic patients have difficulty holding a job or caring for themselves, placing a significant burden on their families and society. Additionally, increased mortality is associated with schizophrenia as patients experience a $20 \%$ shorter lifespan than the general population and are at an increased risk for committing suicide (Newman and Bland, 1991; Goff et al., 2001).

The exact cause(s) for the pathophysiology and progression of schizophrenia are not known; however it is generally accepted that associated symptoms are syndromal in nature, rather than manifestations of a single disease (Carpenter et al., 1999). These symptoms are likely caused by several compounding biochemical abnormalities and influenced by both genetics and environment. Theories as to the origin of these abnormalities focus on the dopaminergic system, but have more recently been expanded to include the serotonergic, $\gamma$-aminobutyric acid-ergic, and glutamatergic systems, as well as the NT system.

One of the earliest and most studied theories is the DA hypothesis of schizophrenia (Carlsson, 1988; Toda and Abi-Dargham, 2007; Howes and Kapur, 2009). While this theory originally emphasized general hyperdopaminergia as a causative factor in schizophrenia (Snyder, 1976), more recent versions focus on the balance of DA within discreet regions of the brain. The current theory predicts that hyperactive subcortical mesolimbic DA projections (resulting in hyperstimulation of $\mathrm{D}_{2}$ receptors) are the main cause for positive symptoms, while hypoactive mesocortical DA projections to the PFC (resulting in hypostimulation of $D_{1}$ receptors) are the main cause for negative symptoms and cognitive impairment (Weinberger, 1987; Toda and Abi-Dargham, 2007). There is strong evidence for a close relationship between the dopaminergic system and NT (Nemeroff, 1986; Kitabgi et al., 1989), suggesting a role for NT in the pathophysiology of schizophrenia.

\section{Neurotensin and schizophrenia}

A role for NT in schizophrenia has been hypothesized for over three decades (Nemeroff, 1980). Specifically, the NT system is closely associated with the dopaminergic system, and deficits in NT neurotransmission have been implicated in the pathophysiology of schizophrenia. Schizophrenics have a $40 \%$ decrease in NTRs in the entorhinal cortex (Wolf et al., 1995), and schizophrenics with decreased NT concentrations in their cerebral spinal fluid have significantly higher levels of pretreatment psychopathology (Sharma et al., 1997).

NT receptors have been detected on DA cell bodies in the SN and VTA (Palacios and Kuhar, 1981; Szigethy and Beaudet, 1989) and NTR activation has an excitatory effect on midbrain DA neurons (Pinnock, 1985; Seutin et al., 1989; Mercuri et al., 1993). NT can inhibit $\mathrm{DA} \mathrm{D}_{2}$ autoreceptor function, thus relieving auto-inhibition of DA transmission (Jomphe et al., 2006) thereby increasing DA release, firing rate, and the synthesis of the rate limiting enzyme for DA synthesis, TH (Binder et al., 2001b). Because of this close association of NT with dopaminergic neurons and its neuromodulatory effects on the dopaminergic system, NT is hypothesized to be therapeutic in the treatment of schizophrenia. Central administration of NT does in fact cause antipsychotic-like 
effects (Jolicoeur et al., 1993), and therefore a great interest exists for developing NT-mimetics for the treatment of neuropsychiatric diseases, such as schizophrenia.

\section{The potential role of NT as an antipsychotic drug}

Several lines of evidence suggest that antipsychotics, the traditional treatment for schizophrenia, act through the induction of endogenous NT (Kinkead et al., 1999): (1) all clinically effective antipsychotic drugs affect in some way the NT system of rats. The therapeutic potency of typical APDs is derived mainly from their ability to antagonize $\mathrm{DA} \mathrm{D}_{2}$ receptors with high affinity (Creese et al., 1976). Typical antipsychotics are associated with extrapyramidal side effects (ESP) characterized by movement disorders including tardive dyskinesia, dystonic reactions, and Parkinsonism. Alternatively, it is suggested that atypical APDs have a higher affinity for $5-\mathrm{HT}_{2 \mathrm{~A}}$ relative to $\mathrm{DA} \mathrm{D}_{2}$ receptors (Meltzer et al., 1989; Nordstrom et al., 1995; Kapur et al., 1998; Gefvert et al., 2001). They are characterized by enhanced antipsychotic efficacy and lower risk of EPS (Meltzer et al., 1989). Both typical and atypical antipsychotics, those associated with little or no EPS, increase NT mRNA in specific regions of the brain after both acute and chronic treatment (Govoni et al., 1980; Merchant et al., 1991, 1992; Merchant and Dorsa, 1993). (2) These effects are selective for drugs with antipsychotic efficacy, and are not seen with other classes of psychotropic drugs. (3) Typical and atypical antipsychotic drugs differentially affect the NT system. Typical antipsychotics act on both the mesolimbic and nigro-striatal NT systems. By contrast, the actions of atypical antipsychotics on NT are thought to be restricted to the mesolimbic system, the region thought to be the site of therapeutic effect in schizophrenia. (4) Centrally administered NT elicits similar behavioral effects as systemically administered atypical antipsychotic drugs. It is hypothesized that the increase in NT neurotransmission in the mesolimbic system mediates the therapeutic effects of APDs, while the increase in NT neurotransmission in the nigrostriatum underlies the propensity to cause ESP (Binder et al., 2001b; Caceda et al., 2006). Interestingly, the pattern of increase in NT mRNA expression, NT tissue content and release (Kinkead et al., 1999) is similar to that of the immediate early genes, $c$-fos, FosB, and $\Delta$ Fos $B$, after acute and chronic administration of typical and atypical APDs (Binder et al., 2001b).

The ability of a compound to inhibit climbing induced by apomorphine (a DA agonist), hyperactivity induced by amphetamine (indirect DA agonist), and to prevent the disruption of prepulse inhibition (PPI) induced by amphetamine [1-(2,5-dimethoxy4-iodophenyl)-2-aminopropane] (DOI) (5- $\mathrm{HT}_{2 \mathrm{~A}}$ agonist), and dizocilpine (non-competitive NMDA antagonist) are tests used to predict antipsychotic-like activity of a drug. These tests also distinguish between typical and atypical antipsychotic-like effects (Merchant and Dorsa, 1993; Arnt et al., 1995) (see review by Geyer and Ellenbroek, 2003). The ability of a compound to block apomorphine-induced climbing over oro-facial stereotypies (sniffing and licking) induced by high doses of apomorphine, suggests atypicality of that compound (Gerhardt et al., 1985).

Neurotensin has been shown to prevent the disruption of amphetamine- and apomorphine-induced PPI (Feifel et al., 1997), as well as attenuate apomorphine-induced climbing (Jolicoeur et al., 1993), and amphetamine- and apomorphine-induced hyperactivity without affecting stereotypy (Jolicoeur et al., 1983). For these reasons it is hypothesized that NT transmission is integral to the mechanism of action of antipsychotic drugs and that NT can serve as an endogenous antipsychotic-like compound (reviewed in Kinkead et al., 1999; Binder et al., 2001b; Kinkead and Nemeroff, 2002).

\section{The behavioral effects of neurotensin analogs in animal models of schizophrenia}

As discussed above, there is strong evidence to support NT as an endogenous antipsychotic drug. However, NT is easily degraded by peptidases and cannot cross the blood-brain barrier. In an effort to study more easily the effects of NT, our group has developed an extensive series of $\mathrm{NT}(8-13)$ analogs that can be delivered peripherally, and that elicit effects similar to centrally administered NT. These NT analogs have demonstrated antipsychotic-like activity similar to endogenous NT as determined by behavioral tests in rats. Most of our work has been with NT69L and NT79. NT69L binds human NTS1 and human NTS2 with high affinity. By contrast, NT79 preferentially binds to NTS2, as its binding affinity for the human NTS2 is approximately 25 -fold higher than that for human NTS1. NT69L (Cusack et al., 2000), NT79 (Boules et al., 2010), and another analog NT77L (Boules et al., 2001c) are each modified from NT at amino acid positions located in the C-terminal 8-13 sequence. Additionally, PD149163, which is a reduced amide bond $\mathrm{NT}(8-13)$ mimetic shows antipsychotic-like activity.

PD149163 has strong affinity for NTRs $\left(K_{\mathrm{i}}=31.2 \mathrm{nM}\right.$ in newborn mouse brain membranes) and improved metabolic stability (Wustrow et al., 1995), a factor that promotes central activity after systemic administration (Banks et al., 1995).

Table 1 shows the structures of some NT analogs.

NT69L elicits similar neurochemical and behavioral effects as endogenous NT (for review, see Boules et al., 2003a). Intraperitoneal delivery of NT69L selectively inhibits stereotyped apomorphine-induced climbing at an $\mathrm{ED}_{50}$ of $16 \mu \mathrm{g} / \mathrm{kg}$, without affecting licking or sniffing at any dose given (Cusack et al., 2000). Additionally, NT69L does not cause catalepsy (muscle rigidity) at any dose given, but reverses haloperidol-induced catalepsy with an $\mathrm{ED}_{50}$ of $0.2 \mathrm{mg} / \mathrm{kg}$ (Cusack et al., 2000). Catalepsy in rats has been used as a predictor of EPS potential of APDs in humans.

NT69L significantly increases both amphetamine- and dizocilpine-induced decreases in PPI with acute administration with an $\mathrm{ED}_{50}$ of 0.08 and $0.05 \mathrm{mg} / \mathrm{kg}$ respectively (Shilling et al., 2003; Boules et al., 2010), as well as with chronic administration (Briody et al., 2010). Additionally, NT69L blocks PCP-induced hyperactivity (Li et al., 2010a), a test that may reflect both positive and negative symptoms of schizophrenia (Snyder, 1980; Javitt and Zukin, 1991). These results demonstrate that NT69L has properties similar to those of atypical APDs.

NT77 is also thought to have antipsychotic-like properties, although less potently than NT69L, based on similar rat behavioral studies (Boules et al., 2001c). NT77L selectively blocks apomorphine-induced climbing with an $\mathrm{ED}_{50}$ of $5.6 \mathrm{mg} / \mathrm{kg}$ without affecting sniffing or licking behavior at any dose. NT77L moderately prevents/reverses the cataleptic effect of haloperidol $\left(\mathrm{ED}_{50} 5.6 \mathrm{mg} / \mathrm{kg}\right)$ while it does not cause catalepsy itself at any dose. The effects of NT77L on PPI have yet to be tested. 
Like NT69L and NT77L, NT79 also selectively blocks apomorphine-induced climbing without affecting sniffing or licking behavior at any dose. Similarly, NT79 significantly blocks amphetamine-induced hyperactivity as well as prevents the disruption of PPI induced by both amphetamine and DOI (Boules et al., 2010). PD149163 antagonizes the reduction in PPI of the rat startle reflex produced by amphetamine and dizocilpine (Feifel et al., 1999), blocks the disruption in PPI induced by the $5-\mathrm{HT}_{2 \mathrm{~A}}$ agonist DOI (Feifel et al., 2003), and inhibits conditioned avoidance responding, which is a highly validated test for screening APD in rats, without causing catalepsy (Holly et al., 2011). These analogs show promise for use in the treatment of schizophrenic symptoms with a lower potential for adverse side effects. The antipsychotic effects of NT analogs are summarized in Table 2.

Studies with the use of knockout mice lacking NT or NTR subtypes suggest a role for NTS1 in the antipsychotic-like effect of NT. NT knockout mice have reduced PPI and are not sensitive to the PPI-disrupting effects of amphetamine as compared to wild type mice. These data indicate the importance of endogenous NT in the effects of amphetamine on PPI (Mechanic et al., 2009). Additionally, the use of NTS1- and NTS2-knockout (NTS1-1and $\mathrm{NTS}^{-l-}$ ) mice revealed hyper-dopaminergic state in the $\mathrm{NTS}^{-1-}$ mice similar to the excessive striatal DA activity reported in schizophrenia (Liang et al., 2010). Furthermore, the NTS1 ${ }^{-1-}$ show changes in behavior, prefrontal cortex neurotransmitters, and protein expression that are similar to wild type mice treated with the psychomimetic PCP, an animal model for schizophrenia (Li et al., 2010c). The involvement of NTS1 in the antipsychoticlike effect of NT has been further demonstrated by the use of NT agonists. Administration of the NT agonists, NT69L and NT2 , reversed apomorphine-induced climbing in wild type but not in NTS1 ${ }^{-1-}$ mice (Mechanic et al., 2009). Likewise, PD149163 significantly facilitates PPI and decreases the acoustic startle response in wild type but not in $\mathrm{NTS}^{-1-}$ mice (Feifel et al., 2010b).

\section{PAIN}

\section{NT and pain}

Neurotensin and NTRs modulate nociception at several different levels (Dobner, 2005). In fact, on a molar basis, NT is more potent than is morphine as an antinociceptive agent (Nemeroff et al., 1979; al-Rodhan et al., 1991). Central administration of NT induces an analgesic response in both the hot plate (HP) and acetic acid-induced writhing tests in rats (Clineschmidt and McGuffin, 1977; Clineschmidt et al., 1979, 1982). NT also produces a longlasting antinociceptive effect in the tail-flick (TF) assay following intra rostroventral medulla (RVM) administration (Fang et al., 1987). These results indicate that NT can influence nociceptive transmission at several different points in the descending pain modulatory circuitry in the brain. There is also limited evidence that NT may affect nociception transmission directly in the spinal cord (Dobner, 2006). Intrathecal NT administration increased both HP and aversive (hypertonic saline) response latencies, but had no significant analgesic effect in the TF (Hylden and Wilcox, 1983). In addition, intrathecal injection of either NT or one of our novel NT(8-13) into the spinal cord of rats modifies pain perception in a rodent model of persistent (Roussy et al., 2006) and of neuropathic pain (Dansereau et al., 2006).

\section{NT receptor subtypes and pain}

The effect of NT on pain modulation is dose-dependent and receptor-selective (Urban and Smith, 1993). NT not only inhibits but also facilitates pain transmission in a dose-dependent manner. High doses (nanomolar range) of the peptide injected into the

Table 1 | Structures of NT analogs.

\begin{tabular}{|c|c|c|c|c|c|c|c|c|c|c|c|c|c|}
\hline & 1 & 2 & 3 & 4 & 5 & 6 & 7 & 8 & 9 & 10 & 11 & 12 & 13 \\
\hline NT & $p$-Glu & I-Leu & I-Tyr & I-Glu & I-Asn & I-Lys & I-Pro & I-Arg & I-Arg & I-Pro & I-Tyr & I-Ile & I-Leu \\
\hline NT69L & - & - & - & - & - & - & - & N-methyl-Arg & I-Lys & I-Pro & I-neo-Trp & Tert-Leu- & I-Leu \\
\hline NT72 & & & & & & & & & d-Lys & I-Pto & I-neo-trp & tert- & I-Leu \\
\hline NT77L & - & - & - & - & - & - & - & I-Arg & d-Orn & I-Pro & I-neo-Trp & tert-Leu & I-Leu \\
\hline NT79 & - & - & - & - & - & - & - & N-methyl-Arg & I-Arg & I-Pro & $\mathrm{d}-3,1-\mathrm{Nal}$ & tert-Leu & I-Leu \\
\hline PD149163 & & & & & & & & H-Lys-psi[CH2NH] & Lys & Pro & Trp & Tle & Leu-Oet \\
\hline
\end{tabular}

Table 2 | Antipsychotic effects of NT analogs.

\begin{tabular}{|c|c|c|c|c|c|}
\hline Analog & $\begin{array}{l}\text { Apomorphine-induced } \\
\text { climbing }\end{array}$ & $\begin{array}{l}\text { Reversal of Haloperidol- } \\
\text { induced catalepsy }\end{array}$ & $\begin{array}{l}\text { Amphetamine-induced decrease } \\
\text { in PPI and hyperactivity }\end{array}$ & $\begin{array}{l}\text { Dizocilpine/DOI-induced } \\
\text { decrease in PPI }\end{array}$ & $\begin{array}{l}\text { PCP-induced } \\
\text { hyperactivity }\end{array}$ \\
\hline NT69L & $Y^{1}$ & $Y^{2}$ & $Y^{3}$ & $Y^{4}$ & $Y^{5}$ \\
\hline NT77L & $Y^{6}$ & $Y^{6}$ & & & \\
\hline NT79 & $Y^{7}$ & $Y^{7}$ & $Y^{7}$ & $Y^{7}$ & \\
\hline PD149163 & & & $Y^{8,9}$ & $Y^{10}$ & \\
\hline
\end{tabular}

$Y=$ has an effect.

${ }^{1}$ Cusack et al. (2000), Mechanic et al. (2009); ${ }^{2}$ Cusack et al. (2000); ${ }^{3}$ Boules et al. (2001a), Shilling et al. (2003), Briody et al. (2010); ${ }^{4}$ Shilling et al. (2003), Secchi et al. (2009); ${ }^{5}$ Li et al. (2010a); ${ }^{6}$ Boules et al. (2001C); ' Boules et al. (2010); ${ }^{8}$ Feifel et al. (2008); ${ }^{9}$ Feifel et al. (1999), Shilling et al. (2004); ${ }^{10}$ Feifel et al. (1999), Feifel et al. (2003), Shilling et al. (2004). 
RVM have an antinociceptive effect as measured by the TF latency (TFL) in response to heat stimulus. In contrast, lower doses (picomolar range) have been shown to reduce latencies in the HP and TF tests, facilitate spinal nociception response, and increase the visceromotor response to noxious heat and visceral stimulation respectively (Urban and Smith, 1993, 1994).

The basis of the opposing actions of NT and its dose-dependent modulation is most probably due to separate and distinct NTR subtype with varying affinity for the peptide (Smith et al., 1997), as well as the involvement of separate and distinct neuronal pathways that modulate pain at the spinal level (Smith et al., 1997). Evidence suggests that both NTS1 and NTS2 mediate the antinociceptive effects of NT, depending upon the antinociceptive test and possibly, the species of rodent used. NTS1 and NTS2 modulate pain-induced behavioral responses by acting on distinct spinal and/or supra-spinal neural circuits (Roussy et al., 2008). Contradictory results have been reported regarding the NTR subtype mediating the antinociceptive effects of NT.

NTS1 and pain. Reports on mice lacking the NTS1 gene reveal that NT and NT analogs fail to induce antinociception in the HP test (Pettibone et al., 2002). Consistent with the knockout mice studies, our group showed that the inhibition of NTS1 synthesis with the use of antisense peptide nucleic acids (PNAs) targeting the NTS1 gene also results in loss of the analgesic properties of NT in the HP test (Tyler et al., 1998b), results that implicate NTS1 in thermal analgesia. Conversely, other evidence that argues against the involvement of NTS1 in the analgesic effect of NT has been reported and summarized by Dubuc et al. (1999a). Thus, as summarized by this group, the analgesic effects of NT are not antagonized by the NTS1-selective antagonist SR48692 (Dubuc et al., 1994), the binding affinity of NT analogs to NTS1 does not correlate with their analgesic effects (Labbe-Jullie et al., 1994), and the administration of antisense oligonucleotides targeted to NTS1 does not reduce NT-induced analgesia in the writhing test in mice (Dubuc et al., 1999b). With respect to formalin-induced pain, Roussy et al. (2010) concluded that NTS1 is important for modulation of persistent pain following systemic administration of morphine in $\mathrm{NTS}^{-/-}$mice.

NTS2 and pain. NTS2 has also been implicated in the analgesic effects of NT (Dubuc et al., 1999b; Remaury et al., 2002; Yamauchi et al., 2003; Maeno et al., 2004; Sarret et al., 2005; Bredeloux et al., 2006). Dubuc et al. showed, with the use of NTS2 oligonucleotides, that NTS2 plays an important role in the writhing test. These data were supported by a close correlation between NT ana$\log$ binding affinity at NTS2 and potency of the analog-induced analgesia in mice (Dubuc et al., 1999b). Maeno et al. (2004) working with mice, suggested that NTS2 plays an important role in thermal nociception. The role of NTS2 in mediating NT-induced analgesia has been based on observations using NTS2 antisense oligodeoxynucleotides and the NTS2 ligand levocabastine (Bredeloux et al., 2006). NTS2 has also been implicated in mediating visceral antinociception (Dubuc et al., 1999a).

\section{NT analogs and pain}

As mentioned, NT must be administered directly into the brain to exert its effect since it gets degraded by peptidases
(Tyler-McMahon et al., 2000a; Boules et al., 2005). Our laboratory has been testing our brain-penetrating stable analogs of NT(8-13) in several animal models of pain.

Studies by our group and others show that NT analogs are effective in treating thermal, visceral (acetic acid-induced writhing), and persistent inflammatory (formalin-induced) pain (TylerMcMahon et al., 2000b; Bredeloux et al., 2008; Boules et al., 2009, 2010; Mechanic et al., 2009). However, as previously stated, evidence suggests that the analgesic efficacy of NT analogs varies with their selectivity for NTS1 and NTS2, the pain model, and, probably, animal species.

Intrathecal injection of the NTS1-selective agonist, PD149163, and the non-selective NT agonist NT69L significantly reduced pain-evoked responses during the inflammatory phase of the formalin test (Roussy et al., 2008). The same analogs also produced potent antiallodynic and antihyperalgesic effects in nerve injured rats, a model of neuropathic pain (Guillemette et al., 2012). Systemic injection of NT analogs NT69L, NT72 (NTS1-selective), and NT77 causes analgesia in the HP test (Tyler et al., 1998a, 1999; Boules et al., 2001c; Smith et al., 2011) with synergy to morphine (Boules et al., 2009). Additionally, NT69L and NT72, significantly reduce acetic acid-induced writhing (Smith et al., 2012).

Supporting the role of NTS2 in antinociception, intrathecal injection of NTS2 agonists levocabastine and JMV431 significantly inhibit the aversive behavior induced by formalin (Roussy et al., 2009) and induced dose-dependent antinociceptive response in the TF test (Sarret et al., 2005).

Interestingly, the NTS2-selective analog, NT79, is ineffective in reducing thermal pain, but blocks acetic acid-induced writhing in rats (Boules et al., 2010), without causing tolerance to its analgesic effects (Smith et al., 2012). It is also interesting that NT79 does not cause hypothermia. Since the NTS1-selective (NT72), and nonselective (NT69L) NT agonists attenuate visceral nociception, it is suggested that both NTR subtypes are involved in mediating visceral analgesia and their roles appear to be NT analog dependent (Smith et al., 2012). Additionally, the NTS2-selective analog, NT79, reduces formalin-induced pain and does so in synergy with morphine (Boules et al., 2011a). Further evidence for the involvement of NTS2 in reducing persistent pain comes with the use of knockout mice. Lafrance et al. (2010) demonstrated that mice lacking NTS2 exhibit significantly lower stress-induced analgesia following cold-water swim stress as compared to their wild type littermates. Table 3 summarizes the analgesic effects of NT analogs.

\section{Analgesic synergy between NT and morphine}

Morphine is a $\mu$-opioid receptor agonist that is widely used for the treatment of many types of chronic pain. However, morphine and other opioids are usually associated with some serious side effects. Additionally, tolerance develops to their analgesic effects, but not to all the side effects, and this tolerance requires dosage increases over time, to attain a consistent level of analgesia. Increasing morphine dosage increases the potential for serious undesired side effects, such as respiratory depression.

Neurotensin exerts a potent $\mu$-opioid-independent, antinociceptive effects in a variety of analgesic screening tests, including tail-flick, HP, and writhing induced by acetic acid (Clineschmidt et al., 1979, 1982; al-Rodhan et al., 1991; Wustrow et al., 1995; 
Table 3 | Analgesic effects of NT analogs.

\begin{tabular}{lcccc}
\hline Analog & Hot plate & Writhing & Formalin & NP \\
\hline NT69L & $Y^{1}$ & $Y^{2}$ & $Y^{3}$ & $Y^{4}$ \\
NT72 & $Y^{2}$ & $Y^{2}$ & & \\
NT77 & $Y^{5}$ & & & \\
NT79 & $N^{6}$ & $Y^{6}$ & $Y^{7}$ & $Y^{8}$ \\
PD149163 & & & $Y^{9}$ & $Y^{4}$ \\
\hline
\end{tabular}

$Y=$ has an effect; $N=$ has no effect.

${ }^{1}$ Tyler-McMahon et al. (2000b), Boules et al. (2009), Smith et al. (2011); ${ }^{2}$ Smith et al. (2012); ${ }^{3}$ Roussy et al. (2008), Roussy et al. (2009); ${ }^{4}$ Guillemette et al. (2012); ${ }^{5}$ Boules et al. (2001 C); ${ }^{6}$ Boules et al. (2010); ${ }^{7}$ Boules et al. (2011a); ${ }^{8}$ Boules et al. (2012); ${ }^{9}$ Roussy et al. (2008), Roussy et al. (2009).

Sarhan et al., 1997). Both NTS2 and $\mu$-opioid receptors have been found in the same brain structures involved in pain perception (Basbaum and Fields, 1984; Asselin et al., 2001) and neurotensinergic system seems to play an important role in the non-opioid form of stress-induced analgesia (Seta et al., 2001; Gui et al., 2004; Lafrance et al., 2010).

The functional analgesic interaction between endogenous NT and the opioid system has been further illustrated by Tershner and Helmstetter. These authors show that the antinociception induced by the $\mu$-opioid receptor activation in the amygdala is partly dependent on the recruitment of NTRs in the ventral PAG (Tershner and Helmstetter, 2000). Additionally, mice rendered tolerant to morphine showed a reduced analgesic effect to NT (Luttinger et al., 1983) and morphine analgesia was considerably reduced in NTS1-deficient mice. These data indicate that the NTS1 actively participates in $\mu$-opioid analgesia (Roussy et al., 2010). Conversely, opioid receptor antagonists do not block NT-mediated antinociception (Clineschmidt et al., 1982; al-Rodhan et al., 1991), but the perfusion of morphine in the PAG increases the extracellular levels of NT-ir in a naloxone-dependent manner (Stiller et al., 1997).

The use of adjuncts such as the NMDA receptor antagonist ketamine in combination with opioids to enhance their efficacy at low doses, and attenuate the occurrence of tolerance has been reported (Lutfy et al., 1996; Nishiyama, 2000). However, serious motor impairment is observed at doses of ketamine that are antinociceptive in the rat and in human, and ketamine can be psychotomimetic. Additionally, long-term exposure of ketamine on spinal tissue leads to tissue necrosis (Vranken et al., 2005). Studies in our laboratory show analgesic synergism between NT analogs and morphine in the use of HP (Boules et al., 2009), in acetic acidinduced writhing, and in formalin-induced pain (Boules et al., 2011a). These studies provide novel potential use for NT analogs in combination with morphine (and perhaps other opioids) to improve the pharmacological treatment of pain while minimizing specific adverse effects of each of the drugs at a higher dose.

\section{NT AND PSYCHOSTIMULANT ABUSE}

Psychostimulants, including nicotine, amphetamine, and cocaine, are drugs that may be employed to improve cognitive and motor function, but can be highly addictive. The mesocorticolimbic system, to which NT colocalizes with DA and other neurotransmitters, provides the anatomic substrate for psychostimulant dependence and craving (McBride et al., 1999; Di Chiara, 2000).
NT acts as a neurotransmitter as well as a modulator of DA and other monoamine neurotransmitter systems and has been linked through several lines of evidence to psychostimulant effects (Richelson et al., 2003).

Behavioral sensitization to psychostimulants, an animal model of addiction, is a process by which repeated administration of the same dose of a drug produces increasing degrees of locomotor effects (Domino, 2001). This process is thought to be due to changes in the NA. Initiation of sensitization is associated with changes in the NA shell, and maintenance of sensitization with changes in the NA core (Iyaniwura et al., 2001; Balfour, 2004). Behavioral sensitization models human acquisition of psychostimulant addiction and risk of relapse (Miller et al., 2001; De Vries et al., 2002).

Locomotor sensitization depends on activation of the mesolimbic DA system with additional long-term influences on glutamate, GABA, $\kappa$-opioid, and other neurotransmitter systems (Pierce and Kalivas, 1997; Hahn et al., 2000). DA neurons originating in the VTA and projecting to the shell and core of the NA lead to the initiation and expression of sensitization, respectively (Pierce and Kalivas, 1997). NT colocalizes with DA neurons and acts as a modulator of DA effects (Binder et al., 2001a). When injected into the VTA, NT causes hyperactivity and DA release in the NA, similar to the effects of psychostimulants (Kalivas and Duffy, 1990; Kalivas, 1994). However, NT injected into the NA reduces the response to psychostimulants, an effect similar to that of brain-penetrating NT analogs given extracranially (Ervin et al., 1981; Robledo et al., 1993; Richelson et al., 2003).

The NT agonist NT69L, given intraperitoneally, blocks the acute locomotor effects of cocaine and $\mathrm{D}$-amphetamine (Boules et al., 2001a), and blocks both the initiation and expression of sensitization to nicotine after subcutaneous administration (Fredrickson et al., 2003a,b). This is one line of evidence suggesting NT agonists may be effective for treatment of nicotine, amphetamine, and cocaine addiction. Curiously, the NT antagonist SR48692 when administered chronically decreased locomotor sensitization to cocaine (Felszeghy et al., 2007).

How then can a NTR agonist and a NTR antagonist have similar effects in this particular animal model of addiction? Although further research is needed, several lines of evidence bear on this question. Repeated doses of the NT antagonist were required to produce the intended effect on sensitization. Classically, chronic receptor blockade can lead to up-regulation of the receptor, thus making the agonist more effective. Chronic blockade of the receptors may also lead to increased NT synthesis and release. Another approach to this question is with animals lacking NTRs. Studies with SR48692 would predict that mice lacking NTS1 would not sensitize to psychostimulants. However, such null mice are more sensitive to an acute injection of $\mathrm{D}$-amphetamine and had an enhanced response to the sensitizing effects of this psychostimulant as compared to wild type mice (Boules et al., 2006).

The NT agonist NT69L attenuates intravenous (IV) selfadministration of nicotine in rats (Boules et al., 2011b). Once animals acquired stable responding to nicotine they were pretreated with either NT69L or saline. Pretreatment with NT69L attenuated nicotine self-infusion under FR1 (fixed ratio of 1) and FR5 schedules of reinforcement. Control rats that were 
response-independent "yoked" as well as rats that self-infused saline showed minimal responses, indicating that nicotine served as a reinforcer. The stimulant and reinforcing effects of nicotine are attributed to stimulation of the mesolimbic DA system (Stein et al., 1998; Di Chiara, 2000; George et al., 2000). In this study, nicotine self-infusion increased $\mathrm{TH}, \mathrm{DA} \mathrm{D}_{1}$, and $\mathrm{DA} \mathrm{D}_{2}$ receptor mRNA in the VTA, consistent with increased burst firing. NT69L antagonized these effects. In the PFC, an area implicated with learning, NT69L increased TH and DA $D_{1}$ mRNA. TH and DA D mRNA levels were also increased in the striatum in response to the NT agonist. Taken together these results show that the NT agonist NT69L attenuated nicotine self-administration and suggest the drug would reduce craving and withdrawal symptoms (for example, cognitive complaints that are common during nicotine withdrawal).

Is there abuse potential for NT agonists? Although NT mimics the effects of psychostimulants when injected directly into the VTA, it blocks certain stimulant effects when injected into the NA. NT analogs given extracranially (native NT is degraded by peptidases when given peripherally) also block locomotor effects of stimulants, and attenuate nicotine self-administration in rats. Rats do not self administer NT. Therefore, the preponderance of evidence argues against an abuse or addiction potential for NT analogs. This conclusion is supported by data in rhesus monkeys; the animals did not self-infuse NT69L (Fantegrossi et al., 2005).

Although questions remain, a growing body of data supports a key role for NT in regulation of responses to psychostimulants. To the extent animal models are predictive, and NT agonists show promise for the treatment of human addiction. The relative contributions of NTS1 and NTS2 receptors in these models have not been extensively explored, and further research may lead to development of agonists which retain efficacy with fewer side effects such as hypothermia and hypotension.

\section{NT AND PARKINSON'S DISEASE}

Studies show that plasma NT concentrations are consistently higher in PD patients as compared to controls and untreated as compared to treated patients (Schimpff et al., 2001). PD patients also have a twofold increase in NT content in both zona compacta and zona reticulate of the SN compared to that for controls (Fernandez et al., 1995). Brains from PD patients have fewer dopaminergic neurons and very low expression of NTS1 (Yamada and Richelson, 1995). Similar results were reported in an animal model for PD, where MPTP treated mice had significantly lower $\left[{ }^{3} \mathrm{H}\right] \mathrm{NT}$ and $\left[{ }^{3} \mathrm{H}\right]$ mazindol binding in the striatum and $\mathrm{SN}$, results indicating severe reduction in NTRs and DA uptake sites respectively. These data suggest that the dysfunction in NTRs may be involved in the degradation processes causing PD. Caceda et al. (2006) suggested that the increase in striatal and nigral NT tissue concentrations, as well as in CSF and plasma levels may be due either to a compensatory mechanism for the loss of DA neurons to preserve motor function and/or to a dysregulation of NT neurotransmission on striatal output favoring the striatopallidal pathway (Caceda et al., 2006). Injection of NT resulted in a dose related attenuation of muscular rigidity and tremors caused by bilateral injection of the neurotoxin 6-hydroxydopamine in the medial forebrain bundle (Jolicoeur et al., 1991). In addition, we showed that injection of the NT agonist, NT69L, attenuated the amphetamine and apomorphine rotatory behavior caused by the unilateral injection of the same drug in the nigro-striatal pathway (Boules et al., 2001b).

\section{POTENTIAL SIDE EFFECTS OF NT AGONISTS HYPOTHERMIA}

Neurotensin (Bissette et al., 1976) and NT agonists (TylerMcMahon et al., 2000b; Boules et al., 2001c, 2003a; Feifel et al., 2010a) elicit hypothermia in rodents. Hypothermia is mediated by NTS1. This has been established with the use of $\mathrm{NTS}^{-1-}$ and NTS2 ${ }^{-1-}$ mice (Remaury et al., 2002; Mechanic et al., 2009). Additionally, NTS2-selective analogs do not induce hypothermia (Boules et al., 2010), results that provide further proof for the involvement of NTS1 receptor subtype in mediating hypothermia. Interestingly, studies show potential therapeutic use for the NT agonist-induced hypothermia. The administration of the NT agonist ABS-201 immediately or up to 60 min after stroke attack significantly reduced infarct formation and brain cell death in an animal model of focal ischemia (Choi et al., 2012). In addition, it was effective in promoting long-term functional recovery in poststroke animals (Choi et al., 2012). Similar studies on regulated hypothermia induced by the NT agonists reduce oxidative stress in the brain during reperfusion from asphyxial cardiac arrest (Katz et al., 2004a). Also, lowering body temperature with a NT agonist provided a better neurologic outcome than brief external cooling in a rat model of near drowning (Katz et al., 2004b). Consistent with these results, hypothermia induced by the NT analog JMV449 had a neuroprotective effect in a mouse model of permanent distal middle cerebral artery occlusion (Torup et al., 2003).

\section{HYPOTENSION}

Intracerebroventricular (ICV) or IV injections of NT induces a dose-dependent drop in arterial blood pressure in anesthetized rats. The drop in blood pressure is of rapid onset (30-60 s) and of short duration (1-4 min) (Rioux et al., 1981). Interestingly, the hypotensive effect of NT is not accompanied by any alteration in cardiac actions (Rosell et al., 1976; Rioux et al., 1981).

\section{DEVELOPMENT OF TOLERANCE}

Animal studies show that tolerance develops to some but not all the effects of NT analogs. Tolerance develops to the hypothermia, thermal analgesia, and anticataleptic effect of NTS1 agonists (Boules et al., 2003b). Conversely, tolerance does not occur to the NT agonist's effects on the reversal of amphetamine- and cocaineinduced locomotor activity (Boules et al., 2003b; Hadden et al., 2005; Feifel et al., 2008), the reversal of apomorphine-induced climbing (Boules et al., 2003b), and the reversal of amphetamine or DOI-induced disruption of PPI (Feifel et al., 2007; Briody et al., 2010).

Interestingly, NTS2 seem to play an important role in the development of tolerance of NT69L-mediated hypothermia and thermal analgesia (Smith et al., 2011), while tolerance to its analgesic and anticataleptic effects the NTS2 analog NT79 does not occur (Boules et al., 2010).

Thus, the development of tolerance depends on the NT analog, their selectivity to the NTR subtypes, the paradigm being tested and the dosing regimen (Wang et al., 2005; Feifel et al., 2008). 


\section{CONCLUSION}

The association of NT with several neurotransmitter and endocrine systems suggests its involvement in a wide range of physiologic processes throughout the body and implicates it in the pathology of many neuropsychiatric diseases. Furthermore, the development of NT analogs that can be administered systemically may provide therapy for the treatment of several disorders including schizophrenia, pain, and psychostimulant abuse. Additionally, the use of NT analogs and genetically modified animals will allow

\section{REFERENCES}

Akema, T., and Kimura, F. (1989). Inhibition by catecholaminergic blockers of the neurotensin-induced enhancement of luteinizing hormone secretion in the ovariectomized estrogen-primed rat. $\mathrm{Neu}$ roendocrinology 50, 688-692.

Alexander, M. J. (1993). Estrogenregulated synthesis of neurotensin in neurosecretory cells of the hypothalamic arcuate nucleus in the female rat. Endocrinology 133, 1809-1816.

Alexander, M. J. (1999). Colocalization of neurotensin messenger ribonucleic acid (mRNA) and progesterone receptor $\mathrm{mRNA}$ in rat arcuate neurons under estrogenstimulated conditions. Endocrinology 140, 4995-5003.

Alexander, M. J., and Leeman, S. E. (1994). Estrogen-inducible neurotensin immunoreactivity in the preoptic area of the female rat. $J$. Comp. Neurol. 345, 496-509.

Alexander, M. J., Mahoney, P. D., Ferris, C. F., Carraway, R. E., and Leeman, S. E. (1989a). Evidence that neurotensin participates in the central regulation of the preovulatory surge of luteinizing hormone in the rat. Endocrinology 124, 783-788.

Alexander, M. J., Dobner, P. R., Miller, M. A., Bullock, B. P., Dorsa, D. M., and Leeman, S. E. (1989b). Estrogen induces neurotensin/neuromedin $\mathrm{N}$ messenger ribonucleic acid in a preoptic nucleus essential for the preovulatory surge of luteinizing hormone in the rat. Endocrinology 125, 2111-2117.

al-Rodhan, N. R., Richelson, E., Gilbert, J. A., McCormick, D. J., Kanba, K. S., Pfenning, M. A., et al. (1991). Structure-antinociceptive activity of neurotensin and some novel analogues in the periaqueductal gray region of the brainstem. Brain Res. 557, 227-235.

Antonelli, T., Fuxe, K., Tomasini, M. C., Mazzoni, E., Agnati, L. F., Tanganelli, S., et al. (2007). Neurotensin receptor mechanisms and its modulation of glutamate transmission in the brain: relevance for neurodegenerative diseases and their treatment. Prog. Neurobiol. 83, 92-109.

Arnt, J., Sanchez, C., Lenz, S. M., Madsen, U., and Krogsgaard-Larsen, P. (1995). Differentiation of in vivo effects of AMPA and NMDA receptor ligands using drug discrimination methods and convulsant/anticonvulsant activity. Eur. J. Pharmacol. 285, 289-297.

Asselin, M. L., Dubuc, I., Coquerel, A., and Costentin, J. (2001). Localization of neurotensin NTS2 receptors in rat brain, using. Neuroreport 12,

Bachelet, C. M., Scarceriaux, V., Rostene, W., and Pelaprat, D. (1997). Evidence for neurotensin autoreceptors and relationship of neurotensin and its receptors with tyrosine hydroxylase-positive neurons in rat primary hypothalamic cultures. Eur. J. Neurosci. 9, 1483-1487.

Balfour, D. J. (2004). The neurobiology of tobacco dependence: a preclinical perspective on the role of the dopamine projections to the nucleus accumbens [corrected]. Nicotine Tob. Res. 6, 899-912.

Banks, W. A., Wustrow, D. J., Cody, W. L., Davis, M. D., and Kastin, A. J. (1995). Permeability of the blood-brain barNT1. Brain Res. 695, 59-63.

Basbaum, A. I., and Fields, H. L. (1984). Endogenous pain control systems: brainstem spinal pathways and endorphin circuitry. Annu. Rev. Neurosci. 7, 309-338.

Bean, A. J., and Roth, R. H. (1992). Dopamine-neurotensin interactions in mesocortical neurons. Evidence from microdialysis studies. Ann. N. Y. Acad. Sci. 668, 43-53.

Beck, B., Stricker-Krongrad, A., Richy, S., and Burlet, C. (1998). Evidence that hypothalamic neurotensin signals leptin effects on feeding behavior in normal and fat-preferring rats. Biochem. Biophys. Res. Commun. 252, 634-638.

Behbehani, M. M. (1992). Physiological mechanisms of the analgesic effect of neurotensin. Ann. N. Y. Acad. Sci. $668,253-265$. 1087-1091. rier to the neurotensin8-13 analog

further understanding of the molecular role of NT in health and disease.

\section{ACKNOWLEDGMENTS}

This work was supported by Mayo Foundation for Medical Education and Research, the Siragusa Foundation Career Development Award in Neuroscience Research, and grant number 2KF01 from the Florida Department of Health to Mona Boules.

Bello, A. R., Reyes, R., Hernandez, G., Negrin, I., Gonzalez, M., Tramu, G., et al. (2004). Developmental expression of neurotensin in thyrotropes and gonadotropes of male and female rats. Neuroendocrinology 79, 90-99.

Berod, A., and Rostene, W. (2002). Neurotensin: an endogenous psychostimulant? Curr. Opin. Pharmacol. 2, 93-98.

Binder, E. B., Kinkead, B., Owens, M. J., and Nemeroff, C. B. (2001a). Neurotensin and dopamine interactions. Pharmacol. Rev. 53, 453-486.

Binder, E. B., Kinkead, B., Owens, M. J., and Nemeroff, C. B. (2001b). The role of neurotensin in the pathophysiology of schizophrenia and the mechanism of action of antipsychotic drugs. Biol. Psychiatry 50, 856-872.

Bissette, G., Nemeroff, C. B., Loosen, P. T., Prange, A. J., and Lipton, M. A. (1976). Hypothermia and intolerance to cold induced by intracisternal administration of the hypothalamic peptide neurotensin. Nature 262, 607-609.

Blackburn, A. M., Fletcher, D. R., Adrian, T. E., and Bloom, S. R. (1980). Neurotensin infusion in man: pharmacokinetics and effect on gastrointestinal and pituitary hormones. J. Clin. Endocrinol. Metab. 51, 1257-1261.

Boudin, H., Pelaprat, D., Rostene, W., Pickel, V. M., and Beaudet, A. (1998). Correlative ultrastructural distribution of neurotensin receptor proteins and binding sites in the rat substantia nigra. J. Neurosci. 18, 8473-8484.

Boules, M., Cusack, B., Zhao, L., Fauq, A., McCormick, D. J., and Richelson, E. (2000). A novel neurotensin peptide analog given extracranially decreases food intake and weight in rodents. Brain Res. 865, 35-44.

Boules, M., Fredrickson, P., and Richelson, E. (2003a). Current topics: brain penetrating neurotensin analog. Life Sci. 73, 2785-2792.

Boules, M., McMahon, B., Wang, R., Warrington, L., Stewart, J., Yerbury, S., et al. (2003b). Selective tolerance to the hypothermic and anticataleptic effects of a neurotensin analog that crosses the blood-brain barrier. Brain Res. 987, 39-48.

Boules, M., Fredrickson, P., and Richelson, E. (2005). Neurotensin agonists as an alternative to antipsychotics. Expert Opin. Investig. Drugs 14, 359-369.

Boules, M., Fredrickson, P., and Richelson, E. (2006). Bioactive analogs of neurotensin. Peptides 27, 2523-2533.

Boules, M., Johnston, H., Tozy, J., Smith, K., Li, Z., and Richelson, E. (2011a) Analgesic synergy of NTS2 receptor agonist (NT79) and morphine. Behav. Pharmacol. 22, 573-581.

Boules, M., Oliveros, A., Liang, Y., Williams, K., Shaw, A., Robinson, J., et al. (2011b). A neurotensin analog, NT69L, attenuates intravenous nicotine self-administration in rats. Neuropeptides 45, 9-16.

Boules, M., Liang, Y., Briody, S., Miura, T., Fauq, I., Oliveros, A., et al. (2010) NT79: a novel neurotensin ana$\log$ with selective behavioral effects. Brain Res. 1308, 35-46.

Boules, M., Shaw, A., Liang, Y., Barbut, D., and Richelson, E. (2009). NT69L, a novel analgesic, shows synergy with morphine. Brain Res. 1294, 22-28.

Boules, M., Warrington, L., Fauq, A., McCormick, D., and Richelson, E. (2001a). A novel neurotensin analog blocks cocaine- and D-amphetamine-induced hyperactivity. Eur. J. Pharmacol. 426, 73-76.

Boules, M., Warrington, L., Fauq, A., McCormick, D., and Richelson, E. (2001b). Antiparkinson-like effects of a novel neurotensin analog in unilaterally 6-hydroxydopamine lesioned rats. Eur. J. Pharmacol. 428, 227-233.

Boules, M., McMahon, B., Warrington, L., Stewart, J., Jackson, J., Fauq, A., et al. (2001c). Neurotensin analog selective for hypothermia over antinociception and exhibiting atypical neuroleptic-like properties. Brain Res. 919, 1-11.

Boules, M., Cai, S., Li, Z., Shukoor, N., and Richelson, E. (2012). NTS2 receptors: novel targets for 
neuropathic pain management. Biol. Psychiatry 71, 302S.

Bozzola, M., Thome, A. N., Giraldi, E., Lhiaubet, A. M., and Schimpff, R. M. (1998a). Plasma neurotensin levels in prepubertal children and adults: possible involvement in the regulation of growth hormone secretion. J. Pediatr. Endocrinol. Metab. 11, 615-621.

Bozzola, M., Ntodou-Thome, A., Bona, G., Autelli, M., Magnani, M. L., Radetti, G., et al. (1998b). Possible role of plasma neurotensin on growth hormone regulation in neonates. J. Pediatr. Endocrinol. Metab. 11, 607-613.

Bredeloux, P., Cavelier, F., Dubuc, I., Vivet, B., Costentin, J., and Martinez, J. (2008). Synthesis and biological effects of $c$ (Lys-Lys-Pro-Tyr-IleLeu-Lys-Lys-Pro-Tyr-Ile-Leu) (JMV2012), a new analogue of neurotensin that crosses the bloodbrain barrier. J. Med. Chem. 51, 1610-1616.

Bredeloux, P., Costentin, J., and Dubuc, I. (2006). Interactions between NTS2 neurotensin and opioid receptors on two nociceptive responses assessed on the hot plate test in mice. Behav. Brain Res. 175, 399-407.

Briody, S., Boules, M., Oliveros, A., Fauq, I., and Richelson, E. (2010). Chronic NT69L potently prevents drug-induced disruption of prepulse inhibition without causing tolerance. Behav. Brain Res. 207, 118-124.

Brouard, A., Pelaprat, D., Dana, C., Vial, M., Lhiaubet, A. M., and Rostene, W. (1992). Mesencephalic dopaminergic neurons in primary cultures express functional neurotensin receptors. J. Neurosci. 12, 1409-1415.

Brunetti, L., Di Nisio, C., Orlando, G., Ferrante, C., and Vacca, M. (2005). The regulation of feeding: a cross talk between peripheral and central signalling. Int. J. Immunopathol. Pharmacol. 18, 201-212.

Buhler, A. V., Choi, J., Proudfit, H. K., and Gebhart, G. F. (2005). Neurotensin activation of the NTR1 on spinally-projecting serotonergic neurons in the rostral ventromedial medulla is antinociceptive. Pain 114, 285-294.

Burgevin, M. C., Castel, M. N., Quarteronet, D., Chevet, T., and Laduron, P. M. (1992a). Neurotensin increases tyrosine hydroxylase messenger RNA-positive neurons in substantia nigra after retrograde axonal transport. Neuroscience 49, 627-633.

Burgevin, M. C., Laduron, P. M., Quarteronnet, D., Chevet, T., and Castel, M. N. (1992b). Striatal injection of neurotensin increases tyrosine hydroxylase mRNA in substantia nigra. Ann. N. Y. Acad. Sci. 668, 311-313.

Caceda, R., Kinkead, B., and Nemeroff, C. B. (2006). Neurotensin: role in psychiatric and neurological diseases. Peptides 27, 2385-2404.

Carlsson, A. (1988). The current status of the dopamine hypothesis of schizophrenia. Neuropsychopharmacology 1, 179-186.

Carpenter, W. T. Jr., and Buchanan, R. W. (1994). Schizophrenia. N. Engl. J. Med. 330, 681-690.

Carpenter, W. T., Kirkpatrick, B., and Buchanan, R. W. (1999). Schizophrenia: syndromes and diseases. J. Psychiatr. Res. 33, 473-475.

Carraway, R., and Leeman, S. E. (1973). The isolation of a new hypotensive peptide, neurotensin, from bovine hypothalami. J. Biol. Chem. 248, 6854-6861.

Choi, K. E., Hall, C. L., Sun, J. M., Wei, L., Mohamad, O., Dix, T. A., et al. (2012). A novel stroke therapy of pharmacologically induced hypothermia after focal cerebral ischemia in mice. FASEB J. 26, 2799-2810.

Clineschmidt, B. V., Martin, G. E., and Veber, D. F. (1982). Antinocisponsive effects of neurotensin and neurotensin-related peptides. Ann. N. Y. Acad. Sci. 400, 283-306.

Clineschmidt, B. V., and McGuffin, J. C. (1977). Neurotensin administered intracisternally inhibits responsiveness of mice to noxious stimuli. Eur. J. Pharmacol. 46, 395-396.

Clineschmidt, B. V., McGuffin, J. C., and Bunting, P. B. (1979). Neurotensin: antinocisponsive action in rodents. Eur. J. Pharmacol. 54, 129-139.

Cooke, J. H., Patterson, M., Patel, S. R., Smith, K. L., Ghatei, M. A., Bloom, S. R., et al. (2009). Peripheral and central administration of xenin and neurotensin suppress food intake in rodents. Obesity (Silver Spring) 17, 1135-1143.

Corley, K. C., Phan, T. H., Daugherty, W. P., and Boadle-Biber, M. C. (2002). Stress-induced activation of median raphe serotonergic neurons in rats is potentiated by the neurotensin antagonist, SR 48692. Neurosci. Lett. 319, 1-4.

Creese, I., Burt, D. R., and Snyder, S. H. (1976). Dopamine receptor binding predicts clinical and pharmacological potencies of antischizophrenic drugs. Science 192, 481-483.

Cui, H., Cai, F., and Belsham, D. D. (2005). Anorexigenic hormones leptin, insulin, and alpha-melanocyte-stimulating hormone directly induce neurotensin (NT) gene expression in novel NT-expressing cell models. $J$. Neurosci. 25, 9497-9506.

Cusack, B., Boules, M., Tyler, B. M. Fauq, A., McCormick, D. J., and Richelson, E. (2000). Effects of a novel neurotensin peptide analog given extracranially on CNS behaviors mediated by apomorphine and haloperidol. Brain Res. 856, 48-54.

Dansereau, M. A., Roussy, G., Belleville, K., Beaudet, N., Richelson, E., et al. (2006). Potent Antinociceptive Effects of NTS1 Agonists in a Model of Neuropathic Pain. Neuroscience Meeting Planner. Society for Neuroscience, Atlanta, GA.

De Vries, T. J., Schoffelmeer, A. N., Binnekade, R., Raaso, H., and Vanderschuren, L. J. (2002). Relapse to cocaine- and heroin-seeking behavior mediated by dopamine D2 receptors is time-dependent and associated with behavioral sensitization. Neuropsychopharmacology 26, 18-26.

Di Chiara, G. (2000). Role of dopamine in the behavioural actions of nicotine related to addiction. Eur. J. Pharmacol. 393, 295-314.

Dobner, P. R. (2005). Multitasking with neurotensin in the central nervous system. Cell. Mol. Life Sci. 62, 1946-1963.

Dobner, P. R. (2006). Neurotensin and pain modulation. Peptides 27, 2405-2414.

Domino, E. F. (2001). Nicotine induced behavioral locomotor sensitization. Prog. Neuropsychopharmacol. Biol. Psychiatry 25, 59-71.

Dubuc, I., Costentin, J., Terranova, J. P., Barnouin, M. C., Soubrie, P., Le Fur, G., et al. (1994). The nonpeptide neurotensin antagonist, SR 48692, used as a tool to reveal putative neurotensin receptor subtypes. Br. J. Pharmacol. 112 , 352-354.

Dubuc, I., Remande, S., and Costentin, J. (1999a). The partial agonist properties of levocabastine in neurotensininduced analgesia. Eur. J. Pharmacol. 381, 9-12.

Dubuc, I., Sarret, P., Labbe-Jullie, C., Botto, J. M., Honore, E., Bourdel, E., et al. (1999b). Identification of the receptor subtype involved in the analgesic effect of neurotensin. J. Neurosci. 19, 503-510.

Feifel, D., Melendez, G., Murray, R. J., Tina Tran, D. N., Rullan, M. A., and Shilling, P. D. (2008). The reversal of amphetamine-induced locomotor activation by a selective neurotensin-1 receptor agonist does not exhibit tolerance. Psychopharmacology (Berl.) 200, 197-203.

Elde, R., Schalling, M., Ceccatelli, S., Nakanishi, S., and Hokfelt, T. (1990). Localization of neuropeptide receptor mRNA in rat brain: initial observations using probes for neurotensin and substance P receptors. Neurosci. Lett. 120, 134-138.

Ervin, G. N., Birkemo, L. S., Nemeroff, C. B., and Prange, A. J. (1981). Neurotensin blocks certain amphetamine-induced behaviours. Nature 291, 73-76.

Fang, F. G., Moreau, J. L., and Fields, H. L. (1987). Dose-dependent antinociceptive action of neurotensin microinjected into the rostroventromedial medulla of the rat. Brain Res. 420, 171-174.

Fantegrossi, W. E., Ko, M. C., Woods, J. H., and Richelson, E. (2005). Antinociceptive, hypothermic, hypotensive, and reinforcing effects of a novel neurotensin receptor agonist, NT69L, in rhesus monkeys. Pharmacol. Biochem. Behav. 80, 341-349.

Farkas, R. H., Chien, P. Y., Nakajima, S., and Nakajima, Y. (1996). Properties of a slow nonselective cation conductance modulated by neurotensin and other neurotransmitters in midbrain dopaminergic neurons. J. Neurophysiol. 76, 1968-1981.

Fawaz, C. S., Martel, P., Leo, D., and Trudeau, L. E. (2009). Presynaptic action of neurotensin on dopamine release through inhibition of $\mathrm{D}(2)$ receptor function. BMC Neurosci. 10:96. doi:10.1186/1471-2202-10-96

Feifel, D., Goldenberg, J., Melendez, G., and Shilling, P. D. (2010a). The acute and subchronic effects of a brainpenetrating, neurotensin-1 receptor agonist on feeding, body weight and temperature. Neuropharmacology 58, 195-198.

Feifel, D., Pang, Z., Shilling, P. D., Melendez, G., Schreiber, R., and Button, D. (2010b). Sensorimotor gating in neurotensin-1 receptor null mice. Neuropharmacology 58, 173-178.

Feifel, D., Melendez, G., Priebe, K., and Shilling, P. D. (2007). The effects of chronic administration of established and putative antipsychotics on natural prepulse inhibition deficits in Brattleboro rats. Behav. Brain Res. 181, 278-286.

Feifel, D., Melendez, G., and Shilling, P. D. (2003). A systemically administered neurotensin agonist blocks disruption of prepulse inhibition produced by a serotonin-2A agonist. Neuropsychopharmacology 28, 651-653. 
Feifel, D., Reza, T. L., and Robeck, S. L. (1997). Pro-dopamine effects of neurotensin on sensorimotor gating deficits. Peptides 18, 1457-1460.

Feifel, D., Reza, T. L., Wustrow, D. J., and Davis, M. D. (1999). Novel antipsychotic-like effects on prepulse inhibition of startle produced by a neurotensin agonist. J. Pharmacol. Exp. Ther. 288, 710-713.

Felszeghy, K., Espinosa, J. M., Scarna, H., Berod, A., Rostene, W., and Pelaprat, D. (2007). Neurotensin receptor antagonist administered during cocaine withdrawal decreases locomotor sensitization and conditioned place preference. Neuropsychopharmacology 32, 2601-2610.

Fernandez, A., Jenner, P., Marsden, C. D., and De Ceballos, M. L. (1995). Characterization of neurotensinlike immunoreactivity in human basal ganglia: increased neurotensin levels in substantia nigra in Parkinson's disease. Peptides 16, 339-346.

Ferraro, L., Beggiato, S., Tomasini, M. C., Fuxe, K., Tanganelli, S., and Antonelli, T. (2011). Neurotensin regulates cortical glutamate transmission by modulating $\mathrm{N}$ methyl-D-aspartate receptor functional activity: an in vivo microdialysis study. J. Neurosci. Res. 89, 1618-1626.

Ferraro, L., O'Connor, W. T., Beggiato, S., Tomasini, M. C., Fuxe, K., Tanganelli, S., et al. (2012). Striatal NTS1, dopamine D2 and NMDA receptor regulation of pallidal GABA and glutamate release - a dual-probe microdialysis study in the intranigral 6-hydroxydopamine unilaterally lesioned rat. Eur. J. Neurosci. 35, 207-220.

Ferraro, L., Tomasini, M. C., Mazza, R., Fuxe, K., Fournier, J., Tanganelli, S., et al. (2008). Neurotensin receptors as modulators of glutamatergic transmission. Brain Res. Rev. 58, 365-373.

Fredrickson, P., Boules, M., Yerbury, S., and Richelson, E. (2003a). Blockade of nicotine-induced locomotor sensitization by a novel neurotensin analog in rats. Eur. J. Pharmacol. 458, 111-118.

Fredrickson, P., Boules, M., Yerbury, S., and Richelson, E. (2003b). Novel neurotensin analog blocks the initiation and expression of nicotineinduced locomotor sensitization. Brain Res. 979, 245-248.

Fuxe, K., Agnati, L. F., von Euler, G., Tanganelli, S., O’Connor, W. T., Ferre, S., et al. (1992a). Neuropeptides, excitatory amino acid and adenosine A2 receptors regulate $\mathrm{D} 2$ receptors via intramembrane receptor-receptor interactions. Relevance for Parkinson's disease and schizophrenia. Neurochem. Int. 20(Suppl.), 215S$224 \mathrm{~S}$.

Fuxe, K., Von Euler, G., Agnati, L. F., Merlo Pich, E., O'Connor,W. T., Tanganelli, S., et al. (1992b). Intramembrane interactions between neurotensin receptors and dopamine D2 receptors as a major mechanism for the neuroleptic-like action of neurotensin. Ann. N. Y. Acad. Sci. 668, 186-204.

Gefvert, O., Lundberg, T., Wieselgren, I. M., Bergstrom, M., Langstrom, B., Wiesel, F., et al. (2001). D(2) and $5 \mathrm{HT}(2 \mathrm{~A})$ receptor occupancy of different doses of quetiapine in schizophrenia: a PET study. Eur. Neuropsychopharmacol. 11, 105-110.

George, T. P., Verrico, C. D., Picciotto, M. R., and Roth, R. H. (2000). Nicotinic modulation of mesoprefrontal dopamine neurons: pharmacologic and neuroanatomic characterization. J. Pharmacol. Exp. Ther. 295, 58-66.

Gerhardt, S., Gerber, R., and Liebman, J. M. (1985). SCH 23390 dissociated from conventional neuroleptics in apomorphine climbing and primate acute dyskinesia models. Life Sci. 37, 2355-2363.

Geyer, M. A., and Ellenbroek, B. (2003). Animal behavior models of the mechanisms underlying antipsychotic atypicality. Prog. Neuropsychopharmacol. Biol. Psychiatry 27, 1071-1079.

Gilbert, J. A., and Richelson, E. (1984). Neurotensin stimulates formation of cyclic GMP in murine neuroblastoma clone N1E-115. Eur. J. Pharmacol. 99, 245-246.

Goff, D. C., Heckers, S., and Freudenreich, O. (2001). Schizophrenia. Med. Clin. North Am. 85, 663-689.

Govoni, S., Hong, J. S., Yang, H. Y., and Costa, E. (1980). Increase of neurotensin content elicited by neuroleptics in nucleus accumbens. $J$. Pharmacol. Exp. Ther. 215, 413-417.

Gui, X., Carraway, R. E., and Dobner, P. R. (2004). Endogenous neurotensin facilitates visceral nociception and is required for stressinduced antinociception in mice and rats. Neuroscience 126, 1023-1032.

Guillemette, A., Dansereau, M. A., Beaudet, N., Richelson, E., and Sarret, P. (2012). Intrathecal administration of NTS1 agonists reverses nociceptive behaviors in a rat model of neuropathic pain. Eur. J. Pain. 16, 473-484.

Hadden, M. K., Orwig, K. S., Kokko, K. P., Mazella, J., and Dix, T. A. (2005). Design, synthesis, and evaluation of the antipsychotic potential of orally bioavailable neurotensin (8-13) analogues containing non-natural arginine and lysine residues. Neuropharmacology 49, 1149-1159.

Hahn, B., Stolerman, I. P., and Shoaib, M. (2000). Kappa-opioid receptor modulation of nicotine-induced behaviour. Neuropharmacology 39, 2848-2855.

Hawkins, M. F. (1986). Central nervous system neurotensin and feeding. Physiol. Behav. 36, 1-8.

Hawkins, M. F., Barkemeyer, C. A., and Tulley, R. T. (1986). Synergistic effects of dopamine agonists and centrally administered neurotensin on feeding. Pharmacol. Biochem. Behav. 24, 1195-1201.

Herbison, A. E., Robinson, J. E., and Skinner, D. C. (1993). Distribution of estrogen receptorimmunoreactive cells in the preoptic area of the ewe: co-localization with glutamic acid decarboxylase but not luteinizing hormone-releasing hormone. Neuroendocrinology 57, 751-759.

Herbison, A. E., and Theodosis, D. T. (1992). Localization of oestrogen receptors in preoptic neurons containing neurotensin but not tyrosine hydroxylase, cholecystokinin or luteinizing hormone-releasing hormone in the male and female rat. Neuroscience 50, 283-298.

Herbison, A. E., and Theodosis, D. T. (1993). Absence of estrogen receptor immunoreactivity in somatostatin (SRIF) neurons of the periventricular nucleus but sexually dimorphic colocalization of estrogen receptor and SRIF immunoreactivities in neurons of the bed nucleus of the stria terminalis. Endocrinology 132, 1707-1714.

Hermans, E., Gailly, P., Octave, J. N., and Maloteaux, J. M. (1994). Rapid desensitization of agonist-induced calcium mobilization in transfected PC12 cells expressing the rat neurotensin receptor. Biochem. Biophys. Res. Commun. 198, 400-407.

Hokfelt, T., Everitt, B. J., Fuxe, K., Kalia, M., Agnati, L., Johansson, O., et al. (1984). Transmitter and peptide systems in areas involved in the control of blood pressure. Clin. Exp. Hypertens. A 6, 23-41.

Holly, E. N., Ebrecht, B., and Prus, A. J. (2011). The neurotensin-1 receptor agonist PD149163 inhibits conditioned avoidance responding without producing catalepsy in rats. Eur. Neuropsychopharmacol. 21, 526-531.

Howes, O. D., and Kapur, S. (2009). The dopamine hypothesis of schizophrenia: version III - the final common pathway. Schizophr. Bull. 35, 549-562.

Hylden, J. L., and Wilcox, G. L. (1983). Antinociceptive action of intrathecal neurotensin in mice. Peptides 4, 517-520.

Ibanez, R., Mallo, F., Benitez, L., Alvarez, C. V., Sanchez-Franco, F., and Dieguez, C. (1993). Effect of neurotensin on growth hormone release in vivo. Life Sci. 53, 227-232.

Iyaniwura, T. T., Wright, A. E., and Balfour, D. J. (2001). Evidence that mesoaccumbens dopamine and locomotor responses to nicotine in the rat are influenced by pretreatment dose and strain. Psychopharmacology (Berl.) 158, 73-79.

Jacobsen, L., Madsen, P., Jacobsen, C., Nielsen, M. S., Gliemann, J., and Petersen, C. M. (2001). Activation and functional characterization of the mosaic receptor SorLA/LR11. J. Biol. Chem. 276, 22788-22796.

Javitt, D. C., and Zukin, S. R. (1991). Recent advances in the phencyclidine model of schizophrenia. Am. J. Psychiatry 148, 1301-1308.

Jiang, Z. G., Pessia, M., and North, R. A. (1994). Neurotensin excitation of rat ventral tegmental neurones. $J$. Physiol. (Lond.) 474, 119-129.

Jolas, T., and Aghajanian, G. K. (1996). Neurotensin excitation of serotonergic neurons in the dorsal raphe nucleus of the rat in vitro. Eur. J. Neurosci. 8, 153-161.

Jolas, T., and Aghajanian, G. K. (1997). Neurotensin and the serotonergic system. Prog. Neurobiol. 52, 455-468.

Jolicoeur, F. B., De Michele, G., Barbeau, A., and St-Pierre, S. (1983). Neurotensin affects hyperactivity but not stereotypy induced by pre and post synaptic dopaminergic stimulation. Neurosci. Biobehav. Rev. 7, 385-390.

Jolicoeur, F. B., Gagne, M. A., Rivest, R., Drumheller, A., and St-Pierre, S. (1993). Atypical neuroleptic-like behavioral effects of neurotensin. Brain Res. Bull. 32, 487-491.

Jolicoeur, F. B., Rivest, R., St-Pierre, S., and Drumheller, A. (1991) Antiparkinson-like effects of neurotensin in 6-hydroxydopamine lesioned rats. Brain Res. 538, 187-192.

Jomphe, C., Lemelin, P. L., Okano, H., Kobayashi, K., and Trudeau, L. E. (2006). Bidirectional regulation of dopamine D2 and neurotensin NTS1 receptors in dopamine neurons. Eur. J. Neurosci. 24, 2789-2800. Kalafatakis, K., and Triantafyllou, K. (2011). Contribution of neurotensin 
in the immune and neuroendocrine modulation of normal and abnormal enteric function. Regul. Pept. $170,7-17$.

Kalivas, P. W. (1994). Blockade of neurotensin-induced motor activity by inhibition of protein kinase. Psychopharmacology (Berl.) 114, 175-180.

Kalivas, P. W., and Duffy, P. (1990). Effect of acute and daily neurotensin and enkephalin treatments on extracellular dopamine in the nucleus accumbens. J. Neurosci. 10, 2940-2949.

Kapur, S., Zipursky, R. B., Remington, G., Jones, C., DaSilva, J., Wilson, A. A., et al. (1998). 5-HT2 and D2 receptor occupancy of olanzapine in schizophrenia: a PET investigation. Am. J. Psychiatry 155, 921-928.

Katz, L. M., Young, A. S., Frank, J. E., Wang, Y., and Park, K. (2004a). Regulated hypothermia reduces brain oxidative stress after hypoxic-ischemia. Brain Res. 1017, 85-91.

Katz, L. M., Young, A., Frank, J. E., Wang, Y., and Park, K. (2004b). Neurotensin-induced hypothermia improves neurologic outcome after hypoxic-ischemia. Crit. Care Med. 32, 806-810.

Kim, E. R., Leckstrom, A., and Mizuno, T. M. (2008). Impaired anorectic effect of leptin in neurotensin receptor 1-deficient mice. Behav. Brain Res. 194, 66-71.

Kim, E. R., and Mizuno, T. M. (2010). Role of neurotensin receptor 1 in the regulation of food intake by neuromedins and neuromedinrelated peptides. Neurosci. Lett. 468 , 64-67.

Kinkead, B., Binder, E. B., and Nemeroff, C. B. (1999). Does neurotensin mediate the effects of antipsychotic drugs? Biol. Psychiatry 46, 340-351.

Kinkead, B., and Nemeroff, C. B. (2002). Neurotensin: an endogenous antipsychotic? Curr. Opin. Pharmacol. 2, 99-103.

Kinkead, B., and Nemeroff, C. B. (2004). Neurotensin, schizophrenia, and antipsychotic drug action. Int. Rev. Neurobiol. 59, 327-349.

Kitabgi, P., De Nadai, F., Labbe-Jullie, C., Dubuc, I., Nouel, D., Costentin, J., et al. (1992). Functional and pharmacological aspects of central neuropeptidergic transmission mediated by neurotensin and neuromedin n. Clin. Neuropharmacol. 15(Suppl. 1) (Pt A), 313A-314A.

Kitabgi, P., Herve, D., Studler, J. M., Tramu, G., Rostene, W., and Tassin, J. P. (1989). Neurotensin/dopamine interactions. Encephale 15, 91-94.
Labbe-Jullie, C., Deschaintres, S., Gully, D., Le Fur, G., and Kitabgi, P. (1994). Effect of the nonpeptide neurotensin antagonist, SR 48692, and two enantiomeric analogs, SR 48527 and SR 49711, on neurotensin binding and contractile responses in guinea pig ileum and colon. J. Pharmacol. Exp. Ther. 271, 267-276.

Lafrance, M., Roussy, G., Belleville, K., Maeno, H., Beaudet, N., Wada, K., et al. (2010). Involvement of NTS2 receptors in stress-induced analgesia. Neuroscience 166, 639-652.

Leinninger, G. M., Opland, D. M., Jo, Y. H., Faouzi, M., Christensen, L., Cappellucci, L. A., et al. (2011). Leptin action via neurotensin neurons controls orexin, the mesolimbic dopamine system and energy balance. Cell Metab. 14, 313-323.

Leiva, L. A., and Croxatto, H. B. (1994). Comparison of the effect of hypothalamic neuropeptides upon luteinizing hormone secretion by cultured rat anterior pituitary cells. Biol. Res. 27, 113-121.

Li, A. H., Yeh, T. H., Tan, P. P., Hwang, H. M., and Wang, H. L. (2001). Neurotensin excitation of serotonergic neurons in the rat nucleus raphe magnus: ionic and molecular mechanisms. Neuropharmacology 40, 1073-1083.

Li, X. M., Ferraro, L., Tanganelli, S., O'Connor, W. T., Hasselrot, U., Ungerstedt, U., et al. (1995). Neurotensin peptides antagonistically regulate postsynaptic dopamine D2 receptors in rat nucleus accumbens: a receptor binding and microdialysis study. J. Neural Transm. Gen. Sect. 102, 125-137.

Li, Z., Boules, M., and Richelson, E. (2011). NT69L blocks ethanolinduced increase of dopamine and glutamate levels in striatum of mouse. Neurosci. Lett. 487, 322-324.

Li, Z., Boules, M., Williams, K., Peris, J., and Richelson, E. (2010a). The novel neurotensin analog NT69L blocks phencyclidine (PCP)-induced increases in locomotor activity and PCP-induced increases in monoamine and amino acids levels in the medial prefrontal cortex. Brain Res. 1311, 28-36.

Li, Z., Liang, Y., Boules, M., Gordillo, A., and Richelson, E. (2010b). Effect of amphetamine on extracellular concentrations of amino acids in striatum in neurotensin subtype 1 and 2 receptor null mice: a possible interaction between neurotensin receptors and amino acid systems for study of schizophrenia. Neuropharmacology 58, 1174-1178.
Li, Z., Boules, M., Williams, K., Gordillo, A., Li, S., and Richelson, E. (2010c). Similarities in the behavior and molecular deficits in the frontal cortex between the neurotensin receptor subtype 1 knockout mice and chronic phencyclidine-treated mice: relevance to schizophrenia. Neurobiol. Dis. 40, 467-477.

Liang, Y., Boules, M., Li, Z., Williams, K. Miura, T., Oliveros, A., et al. (2010). Hyperactivity of the dopaminergic system in NTS1 and NTS2 null mice. Neuropharmacology 58, 1199-1205.

Lopez Ordieres, M. G., and Rodriguez de Lores Arnaiz, G. (2000). Neurotensin inhibits neuronal $\mathrm{Na}+$, $\mathrm{K}+$-ATPase activity through high affinity peptide receptor. Peptides 21 , 571-576.

Lutfy, K., Shen, K. Z., Woodward, R. M., and Weber, E. (1996). Inhibition of morphine tolerance by NMDA receptor antagonists in the formalin test. Brain Res. 731, 171-181.

Luttinger, D., Burgess, S. K., Nemeroff, C. B., and Prange, A. J. (1983). The effects of chronic morphine treatment on neurotensin-induced antinociception. Psychopharmacology (Berl.) 81, 10-13.

Luttinger, D., King, R. A., Sheppard, D., Strupp, J., Nemeroff, C. B., and Prange, A. J. (1982). The effect of neurotensin on food consumption in the rat. Eur. J. Pharmacol. 81, 499-503.

Maeno, H., Yamada, K., Santo-Yamada, Y., Aoki, K., Sun, Y. J., Sato, E., et al. (2004). Comparison of mice deficient in the high- or lowaffinity neurotensin receptors, Ntsr 1 or Ntsr2, reveals a novel function for $\mathrm{Ntsr} 2$ in thermal nociception. Brain Res. 998, 122-129.

Malendowicz, L. K., and Nussdorfer, G. G. (1994). Modulatory action of neurotensin on the pituitaryadrenocortical function in rats: evidence for an acute dose-dependent biphasic effect. Life Sci. 55, 201-205. Martin, S., Vincent, J. P., and Mazella, J. (2003). Involvement of the neurotensin receptor- 3 in the neurotensin-induced migration of human microglia. J. Neurosci. 23, 1198-1205.

Mazella, J. (2001). Sortilin/neurotensin receptor-3: a new tool to investigate neurotensin signaling and cellular trafficking? Cell. Signal. 13, 1-6.

Mazzocchi, G., Malendowicz, L. K. Rebuffat, P., Gottardo, G., and Nussdorfer, G. G. (1997). Neurotensin stimulates $\mathrm{CRH}$ and ACTH release by rat adrenal medulla in vitro. $\mathrm{Neu}$ ropeptides $31,8-11$.
McBride, W. J., Murphy, J. M., and Ikemoto, S. (1999). Localization of brain reinforcement mechanisms: intracranial self-administration and intracranial place-conditioning studies. Behav. Brain Res. 101, 129-152.

McCann, S. M., and Vijayan, E. (1992). Control of anterior pituitary hormone secretion by neurotensin. Ann. N. Y. Acad. Sci. 668, 287-297.

Mechanic, J. A., Sutton, J. E., Berson, A. E., Wu, X., Kwan, J., Schreiber, R., et al. (2009). Involvement of the neurotensin receptor 1 in the behavioral effects of two neurotensin agonists, NT-2 and NT69L: lack of hypothermic, antinociceptive and antipsychotic actions in receptor knockout mice. Eur. Neuropsychopharmacol. 19, 466-475.

Meltzer, H. Y., Matsubara, S., and Lee, J. C. (1989). Classification of typical and atypical antipsychotic drugs on the basis of dopamine D-1, D-2 and serotonin 2 pKi values. J. Pharmacol. Exp. Ther. 251, 238-246.

Memo, M., Castelletti, L., Valerio, A., Missale, C., and Spano, P. F. (1986). Identification of neurotensin receptors associated with calcium channels and prolactin release in rat pituitary. J. Neurochem. 47, 1682-1688.

Merchant, K. M., Dobner, P. R., and Dorsa, D. M. (1992). Differential effects of haloperidol and clozapine on neurotensin gene transcription in rat neostriatum. J. Neurosci. 12, 652-663.

Merchant, K. M., and Dorsa, D. M. (1993). Differential induction of neurotensin and c-fos gene expression by typical versus atypical antipsychotics. Proc. Natl. Acad. Sci. U.S.A. 90, 3447-3451.

Merchant, K. M., Miller, M. A., Ashleigh, E. A., and Dorsa, D. M. (1991). Haloperidol rapidly increases the number of neurotensin mRNAexpressing neurons in neostriatum of the rat brain. Brain Res. 540, 311-314.

Mercuri, N. B., Stratta, F., Calabresi, P., and Bernardi, G. (1993). Neurotensin induces an inward current in rat mesencephalic dopaminergic neurons. Neurosci. Lett. 153, 192-196.

Miller, D. K., Wilkins, L. H., Bardo, M. T., Crooks, P. A., and Dwoskin, L. P. (2001). Once weekly administration of nicotine produces long-lasting locomotor sensitization in rats via a nicotinic receptor-mediated mechanism. Psychopharmacology (Berl.) 156, 469-476.

Motoi, Y., Aizawa, T., Haga, S., Nakamura, S., Namba, Y., and Ikeda, 
K. (1999). Neuronal localization of a novel mosaic apolipoprotein $\mathrm{E}$ receptor, LR11, in rat and human brain. Brain Res. 833, 209-215.

Moyse, E., Miller, M. M., Rostene, W., and Beaudet, A. (1988). Effects of ovariectomy and estradiol replacement on the binding of 125I-neurotensin in rat suprachiasmatic nucleus. Neuroendocrinology $48,53-60$

Mustain, W. C., Rychahou, P. G., and Evers, B. M. (2011). The role of neurotensin in physiologic and pathologic processes. Curr. Opin. Endocrinol. Diabetes Obes. 18, 75-82.

Nemeroff, C. B. (1980). Neurotensin: perchance an endogenous neuroleptic? Biol. Psychiatry 15, 283-302.

Nemeroff, C. B. (1986). The interaction of neurotensin with dopaminergic pathways in the central nervous system: basic neurobiology and implications for the pathogenesis and treatment of schizophrenia. Psychoneuroendocrinology 11, 15-37.

Nemeroff, C. B., Osbahr, A. J., Manberg, P. J., Ervin, G. N., and Prange, A. J. (1979). Alterations in nociception and body temperature after intracisternal administration of neurotensin, beta-endorphin, other endogenous peptides, and morphine. Proc. Natl. Acad. Sci. U.S.A. 76, 5368-5371.

Newman, S. C., and Bland, R. C. (1991). Mortality in a cohort of patients with schizophrenia: a record linkage study. Can. J. Psychiatry 36, 239-245.

Nicot, A., Rostene, W., and Berod, A. (1995). Differential expression of neurotensin receptor mRNA in the dopaminergic cell groups of the rat diencephalon and mesencephalon. J. Neurosci. Res. 40, 667-674.

Niimi, M., Takahara, J., Sato, M., and Kawanishi, K. (1991). Neurotensin and growth hormonereleasing factor-containing neurons projecting to the median eminence of the rat: a combined retrograde tracing and immunohistochemical study. Neurosci. Lett. 133, 183-186.

Nishiyama, T. (2000). Interaction between intrathecal morphine and glutamate receptor antagonists in formalin test. Eur. J. Pharmacol. 395, 203-210.

Nordstrom, A. L., Farde, L., Nyberg, S., Karlsson, P., Halldin, C., and Sedvall, G. (1995). D1, D2, and 5-HT2 receptor occupancy in relation to clozapine serum concentration: a PET study of schizophrenic patients. Am. J. Psychiatry 152, 1444-1449.

Nussdorfer, G. G., Malendowicz, L. K., Meneghelli, V., and Mazzocchi, G. (1992). Neurotensin enhances plasma adrenocorticotropin concentration by stimulating corticotropin-releasing hormone secretion. Life Sci. 50, 639-643.

Nykjaer, A., Lee, R., Teng, K. K., Jansen, P., Madsen, P., Nielsen, M. S., et al. (2004). Sortilin is essential for proNGF-induced neuronal cell death. Nature 427, 843-848.

Palacios, J. M., and Kuhar, M. J. (1981). Neurotensin receptors are located on dopamine-containing neurones in rat midbrain. Nature 294, 587-589.

Pan, J. T., Tian, Y., Lookingland, K. J., and Moore, K. E. (1992). Neurotensin-induced activation of hypothalamic dopaminergic neurons is accompanied by a decrease in pituitary secretion of prolactin and alpha-melanocyte-stimulating hormone. Life Sci. 50, 2011-2017.

Panayi, F., Colussi-Mas, J., LambasSenas, L., Renaud, B., Scarna, H., and Berod, A. (2005). Endogenous neurotensin in the ventral tegmental area contributes to amphetamine behavioral sensitization. Neuropsychopharmacology 30, 871-879.

Petkova-Kirova, P., Rakovska, A., Della Corte, L., Zaekova, G., Radomirov, R., and Mayer, A. (2008). Neurotensin modulation of acetylcholine, GABA, and aspartate release from rat prefrontal cortex studied in vivo with microdialysis. Brain Res. Bull. 77, 129-135.

Pettibone, D. J., Hess, J. F., Hey, P. J., Jacobson, M. A., Leviten, M., Lis, E. V., et al. (2002). The effects of deleting the mouse neurotensin receptor NTR1 on central and peripheral responses to neurotensin. J. Pharmacol. Exp. Ther. 300, 305-313.

Pierce, R. C., and Kalivas, P. W. (1997). A circuitry model of the expression of behavioral sensitization to amphetamine-like psychostimulants. Brain Res. Brain Res. Rev. 25, 192-216.

Pinnock, R. D. (1985). Neurotensin depolarizes substantia nigra dopamine neurones. Brain Res. 338, 151-154.

Poinot-Chazel, C., Portier, M., Bouaboula, M., Vita, N., Pecceu, F., Gully, D., et al. (1996). Activation of mitogen-activated protein kinase couples neurotensin receptor stimulation to induction of the primary response gene Krox-24. Biochem. J. 320, 145-151.

Quirion, R., Gaudreau, P., St-Pierre, S., and Rioux, F. (1982). Localization of neurotensin binding sites in rat kidney. Peptides 3, 765-769.

Rakovska, A., Giovannini, M. G., Della Corte, L., Kalfin, R., Bianchi, L., and
Pepeu, G. (1998). Neurotensin modulation of acetylcholine and GABA release from the rat hippocampus: an in vivo microdialysis study. $\mathrm{Neu}$ rochem. Int. 33, 335-340.

Remaury, A., Vita, N., Gendreau, S., Jung, M., Arnone, M., Poncelet, M., et al. (2002). Targeted inactivation of the neurotensin type 1 receptor reveals its role in body temperature control and feeding behavior but not in analgesia. Brain Res. 953, 63-72.

Richelson, E., Boules, M., and Fredrickson, P. (2003). Neurotensin agonists: possible drugs for treatment of psychostimulant abuse. Life Sci. 73, 679-690.

Rioux, F., Quirion, R., St-Pierre, S., Regoli, D., Jolicoeur, F. B., Belanger, F., et al. (1981). The hypotensive effect of centrally administered neurotensin in rats. Eur. J. Pharmacol. 69, 241-247.

Rivier, C., Brown, M., and Vale, W. (1977). Effect of neurotensin, substance $P$ and morphine sulfate on the secretion of prolactin and growth hormone in the rat. Endocrinology 100, 751-754.

Robledo, P., Maldonado, R., and Koob, G. F. (1993). Neurotensin injected into the nucleus accumbens blocks the psychostimulant effects of cocaine but does not attenuate cocaine self-administration in the rat. Brain Res. 622, 105-112.

Rosell, S., Burcher, E., Chang, D., and Folkers, K. (1976). Cardiovascular and metabolic actions of neurotensin and (Gln4)-Neurotensin. Acta Physiol. Scand. 98, 484-491.

Rostene, W. H., and Alexander, M. J. (1997). Neurotensin and neuroendocrine regulation. Front. Neuroendocrinol. 18, 115-173.

Roussy, G., Beaudry, H., Lafrance, M., Belleville, K., Beaudet, N., Wada, K., et al. (2010). Altered morphineinduced analgesia in neurotensin type 1 receptor null mice. Neuroscience. 170, 1286-1294.

Roussy, G., Dansereau, M. A., Baudisson, S., Ezzoubaa, F., Belleville, K., Beaudet, N., et al. (2009). Evidence for a role of NTS2 receptors in the modulation of tonic pain sensitivity. Mol. Pain 5, 38-52.

Roussy, G., Dansereau, M. A., Belleville, K., Beaudet, N., Richelson, E., and Sarret, P. (2006). NTS1-Preferring Agonists Produce Spinal Antinociception in a Formalin Tonic Pain Model. Neuroscience Meeting Planner. Society for Neuroscience, Atlanta, GA.

Roussy, G., Dansereau, M. A., DoreSavard, L., Belleville, K., Beaudet,
N., Richelson, E., et al. (2008). Spinal NTS1 receptors regulate nociceptive signaling in a rat formalin tonic pain model. J. Neurochem. 105, 1100-1114.

Rowe, W., Viau, V., Meaney, M. J., and Quirion, R. (1995). Stimulation of CRH-mediated ACTH secretion by central administration of neurotensin: evidence for the participation of the paraventricular nucleus. J. Neuroendocrinol. 7, 109-117.

Sahu, A. (1998). Evidence suggesting that galanin (GAL), melanin-concentrating hormone $(\mathrm{MCH})$, neurotensin $(\mathrm{NT})$, proopiomelanocortin (POMC), and neuropeptide Y (NPY) are targets of leptin signaling in the hypothalamus. Endocrinology 139, 795-798.

Sahu, A., Carraway, R. E., and Wang, Y. (2001). Evidence that neurotensin mediates the central effect of leptin on food intake in rat. Brain Res. 888, 343-347.

Sarhan, S., Hitchcock, J. M., Grauffel, C. A., and Wettstein, J. G. (1997). Comparative antipsychotic profiles of neurotensin and a related systemically active peptide agonist. Peptides 18, 1223-1227.

Sarret, P., Esdaile, M. J., Perron, A., Martinez, J., Stroh, T., and Beaudet, A. (2005). Potent spinal analgesia elicited through stimulation of NTS2 neurotensin receptors. J. Neurosci. 25, 8188-8196.

Sarret, P., Krzywkowski, P., Segal, L., Nielsen, M. S., Petersen, C. M., Mazella, J., et al. (2003). Distribution of NTS3 receptor/sortilin mRNA and protein in the rat central nervous system. J. Comp. Neurol. 461, 483-505.

Schimpff, R. M., Avard, C., Fenelon, G., Lhiaubet, A. M., Tenneze, L., Vidailhet, M., et al. (2001). Increased plasma neurotensin concentrations in patients with Parkinson's disease. J. Neurol. Neurosurg. Psychiatr. 70, 784-786.

Schimpff, R. M., Bozzola, M., Lhiaubet, A. M., Spadaro, B., Tettoni, K., and Rostene, W. (1994). Effects of growth hormone administration on neurotensin release in children with growth delay. Horm. Res. 42, 95-99.

Secchi, R. L., Sung, E., Hedley, L. R., Button, D., and Schreiber, R. (2009). The neurotensin agonist NT69L improves sensorimotor gating deficits in rats induced by a glutamatergic antagonist but not by dopaminergic agonists. Behav. Brain Res. 202, 192-197.

Seroogy, K., Ceccatelli, S., Schalling, M., Hokfelt, T., Frey, P., Walsh, J., 
et al. (1988). A subpopulation of dopaminergic neurons in rat ventral mesencephalon contains both neurotensin and cholecystokinin. Brain Res. 455, 88-98.

Seta, K. A., Jansen, H. T., Kreitel, K. D., Lehman, M., and Behbehani, M. M. (2001). Cold water swim stress increases the expression of neurotensin mRNA in the lateral hypothalamus and medial preoptic regions of the rat brain. Brain Res. Mol. Brain Res. 86, 145-152.

Seutin, V. (2005). Dopaminergic neurones: much more than dopamine? Br. J. Pharmacol. 146, 167-169.

Seutin, V., Massotte, L., and Dresse, A. (1989). Electrophysiological effects of neurotensin on dopaminergic neurones of the ventral tegmental area of the rat in vitro. Neuropharmacology 28, 949-954.

Sharma, R. P., Janicak, P. G., Bissette, G., and Nemeroff, C. B. (1997). CSF neurotensin concentrations and antipsychotic treatment in schizophrenia and schizoaffective disorder. Am. J. Psychiatry 154, 1019-1021.

Shi, W. X., and Bunney, B. S. (1992). Roles of intracellular cAMP and protein kinase $\mathrm{A}$ in the actions of dopamine and neurotensin on midbrain dopamine neurons. J. Neurosci. 12, 2433-2438.

Shilling, P. D., Melendez, G., Priebe, K., Richelson, E., and Feifel, D. (2004). Neurotensin agonists block the prepulse inhibition deficits produced by a 5 -HT(2A) and an alpha(1) agonist. Psychopharmacology (Berl.) 175, 353-359.

Shilling, P. D., Richelson, E., and Feifel, D. (2003). The effects of systemic NT69L, a neurotensin agonist, on baseline and drug-disrupted prepulse inhibition. Behav. Brain Res. 143, 7-14.

Shivers, B. D., Harlan, R. E., Morrell, J. I., and Pfaff, D. W. (1983). Absence of oestradiol concentration in cell nuclei of LHRH-immunoreactive neurones. Nature 304, 345-347.

Slusher, B. S., Zacco, A. E., Maslanski, J. A., Norris, T. E., McLane, M. W., Moore, W. C., et al. (1994). The cloned neurotensin receptor mediates cyclic GMP formation when coexpressed with nitric oxide synthase cDNA. Mol. Pharmacol. 46, 115-121.

Smith, D. J., Hawranko, A. A., Monroe, P. J., Gully, D., Urban, M. O., Craig, C. R., et al. (1997). Dosedependent pain-facilitatory and inhibitory actions of neurotensin are revealed by SR 48692 , a nonpeptide neurotensin antagonist: influence on the antinociceptive effect of morphine. J. Pharmacol. Exp. Ther. 282, 899-908.

Smith, E., Boules, M., Williams, K., Fauq, A., and Richelson, E. (2011). The role of NTS2 in the development of tolerance to NT69L in mouse models for hypothermia and thermal analgesia. Behav. Brain Res. 224, 344-349.

Smith, K. E., Boules, M., Williams, K., and Richelson, E. (2012). NTS1 and NTS2 mediate analgesia following neurotensin analog treatment in a mouse model for visceral pain. Behav. Brain Res. 232, 93-97.

Smith, M. J., and Wise, P. M. (2001). Neurotensin gene expression increases during proestrus in the rostral medial preoptic nucleus: potential for direct communication with gonadotropin-releasing hormone neurons. Endocrinology 142, 3006-3013.

Snyder, S. H. (1976). The dopamine hypothesis of schizophrenia: focus on the dopamine receptor. Am. J. Psychiatry 133, 197-202.

Snyder, S. H. (1980). Phencyclidine. Nature 285, 355-356.

Stein, E. A., Pankiewicz, J., Harsch, H. H., Cho, J. K., Fuller, S. A., Hoffmann, R. G., et al. (1998). Nicotineinduced limbic cortical activation in the human brain: a functional MRI study. Am. J. Psychiatry 155, 1009-1015.

St-Gelais, F., Jomphe, C., and Trudeau, L. E. (2006). The role of neurotensin in central nervous system pathophysiology: what is the evidence? J Psychiatry Neurosci 31, 229-245.

Stiller, C. O., Gustafsson, H., Fried, K., and Brodin, E. (1997). Opioidinduced release of neurotensin in the periaqueductal gray matter of freely moving rats. Brain Res. 774, 149-158.

Stolakis, V., Kalafatakis, K., Botis, J., Zarros, A., and Liapi, C. (2010). The regulatory role of neurotensin on the hypothalamic-anterior pituitary axons: emphasis on the control of thyroid-related functions. Neuropeptides 44, 1-7.

Szigethy, E., and Beaudet, A. (1989). Correspondence between high affinity $125 \mathrm{I}$-neurotensin binding sites and dopaminergic neurons in the rat substantia nigra and ventral tegmental area: a combined radioautographic and immunohistochemical light microscopic study. J. Comp. Neurol. 279, 128-137.

Tanganelli, S., Antonelli, T., Tomasini, M. C., Beggiato, S., Fuxe, K., and Ferraro, L. (2012). Relevance of dopamine $\mathrm{D}(2) /$ neurotensin NTS1 and NMDA/neurotensin NTS1 receptor interaction in psychiatric and neurodegenerative disorders. Curr. Med. Chem. 19, 304-316.

Tershner, S. A., and Helmstetter, F. J. (2000). Antinociception produced by mu opioid receptor activation in the amygdala is partly dependent on activation of mu opioid and neurotensin receptors in the ventral periaqueductal gray. Brain Res. 865 $17-26$.

Thibault, D., Albert, P. R., Pineyro, G., and Trudeau, L. E. (2011). Neurotensin triggers dopamine D2 receptor desensitization through a protein kinase $\mathrm{C}$ and beta-arrestin 1dependent mechanism. J. Biol. Chem. 286, 9174-9184.

Toda, M., and Abi-Dargham, A. (2007). Dopamine hypothesis of schizophrenia: making sense of it all. Curr Psychiatry Rep 9, 329-336.

Torup, L., Borsdal, J., and Sager, T. (2003). Neuroprotective effect of the neurotensin analogue JMV-449 in a mouse model of permanent middle cerebral ischaemia. Neurosci. Lett. 351, 173-176.

Trudeau, L. E. (2000). Neurotensin regulates intracellular calcium in ventral tegmental area astrocytes: evidence for the involvement of multiple receptors. Neuroscience 97, 293-302.

Tyler, B. M., Douglas, C. L., Fauq, A. Pang, Y. P., Stewart, J. A., Cusack, B., et al. (1999). In vitro binding and CNS effects of novel neurotensin agonists that cross the blood-brain barrier. Neuropharmacology 38, 1027-1034.

Tyler, B. M., Groshan, K., Cusack, B., and Richelson, E. (1998a). In vivo studies with low doses of levocabastine and diphenhydramine, but not pyrilamine, antagonize neurotensin-mediated antinociception. Brain Res. 787, 78-84.

Tyler, B. M., McCormick, D. J., Hoshall, C. V., Douglas, C. L., Jansen, K., Lacy, B. W., et al. (1998b). Specific gene blockade shows that peptide nucleic acids readily enter neuronal cells in vivo. FEBS Lett. 421, 280-284.

Tyler-McMahon, B. M., Boules, M., and Richelson, E. (2000a). Neurotensin: peptide for the next millennium. Regul. Pept. 93, 125-136.

Tyler-McMahon, B. M., Stewart, J. A., Farinas, F., McCormick, D. J., and Richelson, E. (2000b). Highly potent neurotensin analog that causes hypothermia and antinociception. Eur. J. Pharmacol. 390, 107-111.
Urban, M. O., and Smith, D. J. (1993). Role of neurotensin in the nucleus raphe magnus in opioid-induced antinociception from the periaqueductal gray. J. Pharmacol. Exp. Ther. 265, 580-586.

Urban, M. O., and Smith, D. J. (1994). Localization of the antinociceptive and antianalgesic effects of neurotensin within the rostral ventromedial medulla. Neurosci. Lett. 174, 21-25.

Vijayan, E., Carraway, R., Leeman, S. E., and McCann, S. M. (1988). Use of antiserum to neurotensin reveals a physiological role for the peptide in rat prolactin release. Proc. Natl. Acad. Sci. U.S.A. 85, 9866-9869.

Vranken, J. H., Troost, D., Wegener, J. T., Kruis, M. R., and van der Vegt, M. H. (2005). Neuropathological findings after continuous intrathecal administration of $\mathrm{S}(+)$ ketamine for the management of neuropathic cancer pain. Pain 117, 231-235.

Wang, R., Boules, M., Gollatz, E., Williams, K., Tiner, W., and Richelson, E. (2005). Effects of 5 daily injections of the neurotensinmimetic NT69L on the expression of neurotensin receptors in rat brain. Brain Res. Mol. Brain Res. 138, 24-34.

Watanobe, H., and Takebe, K. (1993). In vivo release of neurotensin from the median eminence of ovariectomized estrogen-primed rats as estimated by push-pull perfusion: correlation with luteinizing hormone and prolactin surges. Neuroendocrinology 57, 760-764.

Watson, M. A., Yamada, M., Cusack, B., Veverka, K., Bolden-Watson, C., and Richelson, E. (1992). The rat neurotensin receptor expressed in Chinese hamster ovary cells mediates the release of inositol phosphates. J. Neurochem. 59, 1967-1970.

Weinberger, D. R. (1987). Implications of normal brain development for the pathogenesis of schizophrenia. Arch. Gen. Psychiatry 44, 660-669.

Wolf, S. S., Hyde, T. M., Saunders, R. C., Herman, M. M., Weinberger, D. R., and Kleinman, J. E. (1995). Autoradiographic characterization of neurotensin receptors in the entorhinal cortex of schizophrenic patients and control subjects. J. Neural Transm. Gen. Sect. 102, 55-65.

Woulfe, J., and Beaudet, A. (1989). Immunocytochemical evidence for direct connections between neurotensin-containing axons and dopaminergic neurons in the rat 
ventral midbrain tegmentum. Brain Res. 479, 402-406.

Wustrow, D. J., Davis, M. D., Akunne, H. C., Corbin, A. E., Wiley, J. N., Wise, L. D., et al. (1995). Reduced amine bond neurotensin 8-13 mimetics with potent in vivo activity. Bioorg. Med. Chem. Lett. 5, 997-1002.

Yamada, M., and Richelson, E. (1993). Role of signal transduction systems in neurotensin receptor downregulation induced by agonist in murine neuroblastoma clone N1E115 cells. J. Pharmacol. Exp. Ther. 267, 128-133.

Yamada, M., and Richelson, E. (1995). Heterogeneity of melanized neurons expressing neurotensin receptor messenger RNA in the substantia nigra and the nucleus paranigralis of control and Parkinson's disease brain. Neuroscience 64, 405-417.

Yamauchi, R., Sonoda, S., Jinsmaa, Y., and Yoshikawa, M. (2003). Antinociception induced by betalactotensin, a neurotensin agonist peptide derived from betalactoglobulin, is mediated by NT2 and D1 receptors. Life Sci. 73, 1917-1923.

Zhang, X., Nicholas, A. P., and Hokfelt, T. (1995). Ultrastructural studies on peptides in the dorsal horn of the rat spinal cord - II. Co-existence of galanin with other peptides in local neurons. Neuroscience 64 875-891.

Conflict of Interest Statement: Drs Richelson, Fredrickson, and Boules have a U.S. Patent \# 7,087,575, August 8, 2006. "Treating the Effect of Nicotine: Elliott Richelson, Paul Fredrickson, Mona Boules."

Received: 31 August 2012; accepted: 06 March 2013; published online: 22 March 2013.

Citation: Boules $M, \quad \mathrm{Li} Z$, Smith $K$, Fredrickson $P$ and Richelson $E$
(2013) Diverse roles of neurotensin agonists in the central nervous system. Front. Endocrinol. 4:36. doi: 10.3389/fendo.2013.00036

This article was submitted to Frontiers in Neuroendocrine Science, a specialty of Frontiers in Endocrinology.

Copyright (C) 2013 Boules, Li, Smith, Fredrickson and Richelson. This is an open-access article distributed under the terms of the Creative Commons Attribution License, which permits use, distribution and reproduction in other forums, provided the original authors and source are credited and subject to any copyright notices concerning any third-party graphics etc. 